\title{
Applications of Graphene and Its Derivatives in Bone Repair: Advantages for Promoting Bone Formation and Providing Real-Time Detection, Challenges and Future Prospects
}

This article was published in the following Dove Press journal:

International Journal of Nanomedicine

\begin{abstract}
Zhipo Du (D) ${ }^{1, *}$
Cunyang Wang $\mathbb{D}^{2, *}$

Ruihong Zhang $\mathbb{B}^{3}$

Xiumei Wang ${ }^{4}$

Xiaoming $\mathrm{Li}\left(\mathbb{D}^{2}\right.$

'Department of Orthopedics, The Fourth Central Hospital of Baoding City, Baoding 072350, Hebei Province, People's Republic of China; ${ }^{2}$ Key Laboratory for Biomechanics and Mechanobiology of Ministry of Education, School of Biological Science and Medical Engineering, Beijing Advanced Innovation Center for Biomedical Engineering, Beihang University, Beijing 100083, People's Republic of China; ${ }^{3}$ Department of Research and Teaching, The Fourth Central Hospital of Baoding City, Baoding 072350, Hebei Province, People's Republic of China; ${ }^{4}$ Key Laboratory of Advanced Materials of Ministry of Education, Tsinghua University, Beijing I00084, People's Republic of China
\end{abstract}

*These authors contributed equally to this work

Correspondence: Ruihong Zhang;

Xiaoming $\mathrm{Li}$

Tel $+86-3 \mid 2-6413166$

Tel +86-10-823|6467

Email 13931391449@I63.com;

x.m.li@hotmail.com

\begin{abstract}
During continuous innovation in the preparation, characterization and application of various bone repair materials for several decades, nanomaterials have exhibited many unique advantages. As a kind of representative two-dimensional nanomaterials, graphene and its derivatives (GDs) such as graphene oxide and reduced graphene oxide have shown promising potential for the application in bone repair based on their excellent mechanical properties, electrical conductivity, large specific surface area (SSA) and atomic structure stability. Herein, we reviewed the updated application of them in bone repair in order to present, as comprehensively, as possible, their specific advantages, challenges and current solutions. Firstly, how their advantages have been utilized in bone repair materials with improved bone formation ability was discussed. Especially, the effects of further functionalization or modification were emphasized. Then, the signaling pathways involved in GDs-induced osteogenic differentiation of stem cells and immunomodulatory mechanism of GDs-induced bone regeneration were discussed. On the other hand, their applications as contrast agents in the field of bone repair were summarized. In addition, we also reviewed the progress and related principles of the effects of GDs parameters on cytotoxicity and residues. At last, the future research was prospected.
\end{abstract}

Keywords: graphene, graphene oxide, bone repair, real-time detection, signaling pathways

\section{Introduction}

In recent years, due to the increasing incidence of bone defects caused by different reasons, such as post-traumatic, degenerative, neoplastic or congenital, bone transplantation has become the second largest tissue transplantation after blood transfusion. ${ }^{1-3}$ Although autogenous bone transplantation is still considered as the gold standard for bone repair, the application of this method is limited owing to the lack of autogenous materials and the occurrence of secondary defects at the bone donor site. $^{4-6}$ Consequently, there has been an urgent need for the development and application of bone repair materials. During continuous innovation in the preparation, characterization and application of various bone repair materials for several decades, nanomaterials have exhibited some unique advantages. For example, the structure of some nanomaterials is similar to that of the natural bone, and they have special characteristics such as outstanding mechanical properties, desired electrochemical capacities, increased surface area and satisfactory wettability, ${ }^{7,8}$ which 
could not only provide structural support for cells, but also regulate their proliferation, differentiation and migration, and ultimately improve the effect of bone repair. 9,10

Currently, as a representative two-dimensional nanomaterial, graphene and its derivatives (GDs) have been shown promising potential for the application in bone repair based on their excellent mechanical properties, electrical conductivity, large specific surface area (SSA) and atomic structure stability. ${ }^{11,12}$ It has been demonstrated that GDs can provide sufficient mechanical reinforcement to bone repair scaffolds, ${ }^{13}$ bring desired electrical stimulation to cell osteogenic activities and bone formation, ${ }^{14}$ and be conducive to the adsorption of active substances. ${ }^{15}$ Moreover, the hexagonal single-layer carbon atomic structure of graphene makes strong structural stability, which is not easy to be destroyed during complex scaffold preparation process with organic solvents and at the implantation sites under physiological environments. ${ }^{16}$ But, pure graphene particles are difficult to form a $3 \mathrm{D}$ scaffold themselves and have poor fluidity to inject into the body, so they have been normally compounded with other substrates to use in bone repair. ${ }^{17}$ However, because pure graphene particles are easy to agglomerate due to strong van der Waals force, which makes it difficult for GDs to uniformly disperse into composites, ${ }^{18}$ they usually need to undergo functionalization before use. ${ }^{19,20}$ In most cases, the preparation of graphene oxide (GO) is the first step for their functionalization. ${ }^{21,22}$ On the basis of GO, it is possible for carboxyl, ${ }^{23}$ amino, ${ }^{24}$ hydroxyl ${ }^{25}$ and other functional groups to be introduced not only to improve the fluidity and dispersion of graphene, but also to further endow it with new functions, among which is that various active substances can be loaded to improve bioactivities. ${ }^{26,27}$ At present, the functionalized GDs have been compounded with various substrates such as metals, ${ }^{28}$ inorganic, ${ }^{29}$ natural polymer $^{30}$ and synthetic polymer ${ }^{31}$ to prepare scaffolds, ${ }^{32,33}$ coatings, ${ }^{34}$ membranes ${ }^{35}$ and injectable hydrogels. ${ }^{36}$ Lots of studies in vitro and in vivo have demonstrated that the GDscontaining composites could regulate the extracellular microenvironment to effectively promote bone regeneration. It has been shown that GDs could not only promote the adhesion, proliferation and mineralization of osteoblasts, ${ }^{37,38}$ but also maintain the activity of bone marrow mesenchymal stem cells and those derived from soft tissues and induce them to differentiate into osteogenic cells. ${ }^{39,40}$ Further studies into related signaling pathways demonstrated that the GDs achieved the osteogenic performances by activating some specific signaling pathways, such as Wingless/Integrated (Wnt)/ $\beta$-catenin, ${ }^{41}$ Phosphatidylinositol kinase (PI3K)/
Protein kinase B (Akt)/Glycogen synthase kinase-3 (GSK$3 \beta) / \beta$-catenin, ${ }^{42} \quad$ Mitogen-activated protein kinases $(\mathrm{MAPK})^{43}$ of mesenchymal stem cells, and Wnt and bone morphogenetic protein (BMP) ${ }^{44}$ of monocytes and macrophages. Moreover, in vivo experiments of the skull and radius defect models of various animals such as murines, ${ }^{45}$ rabbits ${ }^{46}$ and canines ${ }^{47}$ have demonstrated that the GDs could significantly promote bone repair.

In addition, it has been indicated that GDs could be applied to real-time detection of bone repair process. After GDs were modified with functional groups or combined with fluorescent/magnetic molecules, the imaging efficiency of the GDs-containing composites with various detection equipment such as computed tomography $(\mathrm{CT}),{ }^{48}$ ultrasound $^{49}$ and nuclear magnetic resonance $(\mathrm{NMR})^{50}$ could be significantly improved, by which the structural integrity, ${ }^{51}$ tumorigenicity, ${ }^{52}$ degradability ${ }^{53}$ and mineralization $^{54}$ of the composites could be real-timely evaluated, which was definitely helpful for further and deeper study of the bone repair process. Compared with most of other substrate contrast agents, GDs could be more conducive to the quantitative control of loaded fluorescent markers or paramagnetic substances ${ }^{55}$ based on their excellent conductivity and large SSA. Moreover, the imaging performances of GDs could be further changed and optimized by functionalization. ${ }^{56}$

Although GDs have exhibited attractive advantages in the bone repair application, as shown above, there are still some concerns, the main two aspects of which are their potential toxicity and possible residue in vivo. The current related studies demonstrated that the potential toxicity of GDs was dependent on their size, concentration, functionalization and formed structure, etc. For example, the graphene nanosheets with smaller size $(<100 \mathrm{~nm})$ had bigger potential toxicity than those with larger size $(>400$ $\mathrm{nm}){ }^{57}$ The concentration of GDs greater than $10 \mu \mathrm{g} / \mathrm{mL}$ might inhibit the proliferation of bone marrow mesenchymal stem cells. ${ }^{58}$ Functionalization could decrease toxicity potential of GDs to some extent. ${ }^{59}$ In addition, the GDs in sheet structures ${ }^{60}$ or compounded with other materials ${ }^{61}$ could bring lower toxicity risk because of decreased possibility in penetration into the cell membrane. On the other hand, the degradation of GDs has been shown to be closely related to their layer number, introduction of other atoms, binding of functional groups, and compounding with degradable polymers. For example, improving the dispersion of GDs was beneficial to increase the contact between GDs and enzyme, thus promoting the degradation 


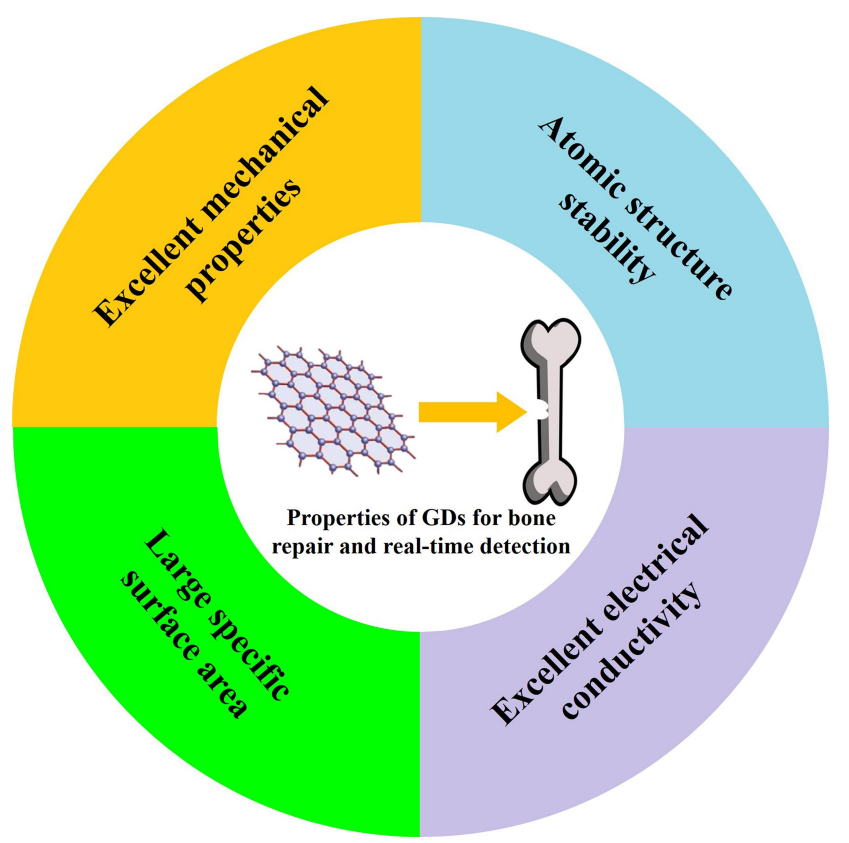

Figure I The various properties of GDs for bone repair and real-time detection.

of GDs. ${ }^{62}$ Single-layer or low-layer GDs could be relatively more easily degraded by specific enzymes around the implantation site, such as peroxidase. ${ }^{63}$ Covalent bonds of some specific functional groups such as phosphate groups could regulate the biodegradation of GDs by improving the interactions between the GDs and enzymes. ${ }^{64}$ Moreover, compounding with some degradable polymers such as polycaprolactone (PCL) was demonstrated beneficial to the excretion of GDs with the degradation products. ${ }^{65}$
Herein, we reviewed the updated application of GDs in bone repair in order to present as comprehensively as possible their specific advantages (Figure 1), challenges and possible solutions. Finally, future prospects were proposed.

\section{Utilization of Advantages of GDs in Bone Repair Materials}

As shown above, GDs have exhibited many advantages that present great potential to directly or indirectly promote bone repair (Figure 2). In this section, how the various advantages of GDs have been utilized in bone repair materials was discussed. Especially, the effects of further functionalization or modification of GDs were emphasized.

\section{Outstanding Mechanical Properties}

It has been well recognized that the mechanical properties of bone repair materials have important effects on their performances. ${ }^{66-69}$ In this subsection, the main factors that have been shown to significantly influence the reinforcing effect of GDs were focused.

Graphene is a monolayer carbon atom composed of $\mathrm{sp} 2$ hybrid C-C bond, which has excellent mechanical properties because of its huge bond energy. ${ }^{70,71}$ At present, graphene is considered to be the strongest substance and harder even than diamond, Young's modulus, stiffness and fracture strength of which could be up to $1.0 \mathrm{TPa}, 2.0 \mathrm{TPa}$ and $130 \mathrm{GPa}$, respectively. ${ }^{72-74}$ Current studies have

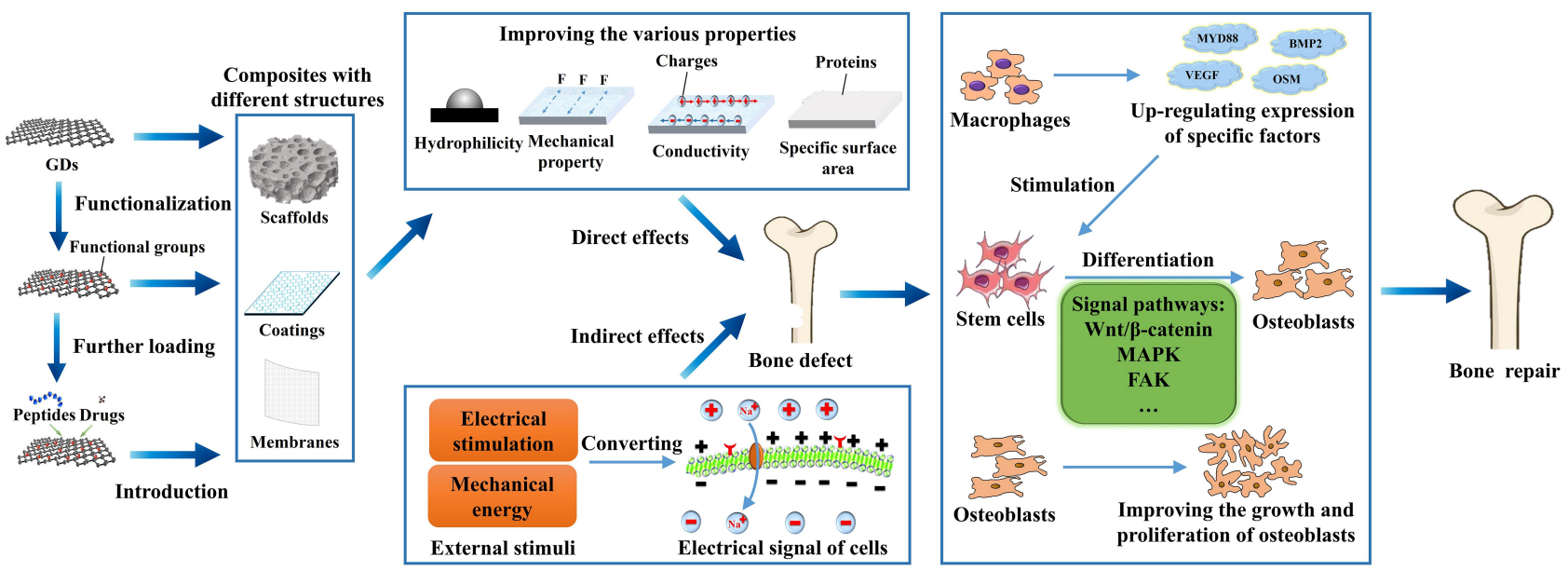

Figure 2 Schematic diagram showing how GDs promote bone repair. GDs can be prepared into composites with different structures and enhance their various properties, which directly improve the functions of bone-related cells or indirectly promote them with external stimuli, such as the growth and proliferation of osteoblasts, osteogenic differentiation of stem cells by activating some specific signal pathways, and up-regulated expression of specific factors of macrophages that further stimulate osteogenic differentiation of stem cells, etc., thereby inducing bone regeneration. 
demonstrated GDs possess an outstanding potential to significantly reinforce bone repair materials, the effect of which is mainly dependent on the layer number, content and uniformity of the GDs in the matrix, and the binding mode between GDs and the matrix.

Firstly, it should be noticed that the increase of graphene layers could normally lead to the decrease of their mechanical properties, which was mainly due to the fact that there was no covalent bond connection between the layers, but only a relatively weak van der Waals force. ${ }^{75-77}$ For example, Eqra et $\mathrm{al}^{75}$ reinforced epoxy resin with $<10$ layers of graphene $(\mathrm{GEC} 10)$ and $<30$ layers of graphene (GEC30), the results of which showed that when the content of graphene was $0.1 \mathrm{wt} \%$, the tensile strength of GEC10 and GEC30 samples both reached the maximum, and the peak tensile strength of GEC10 samples was $4.8 \%$ higher than that of GEC30 samples.

Another aspect that needed to be highlighted was that with the increase of GDs content in the matrix, the mechanical properties of the composites would normally firstly increase and then decrease, which was mainly caused by agglomeration of GDs and the change of reinforcing mechanism. ${ }^{78-80}$ For example, Tang et $\mathrm{al}^{78}$ introduced graphene into barium titanate/polymethyl methacrylate composites in order to obtain bone repair materials with both biological activity and satisfactory mechanical properties. As shown in Figure 3A- F, the results showed that the introduction and dispersion of graphene had a significant influence on the reinforcing effect. When the graphene content was $0.5 \mathrm{wt} . \%$, the compressive strength of the composite increased from 83.5 $\mathrm{MPa}$ to 89.5 $\mathrm{MPa}$. However, with the further increase of graphene content, the compressive strength of the composites decreased gradually. Due to the accumulation of graphene, there was a phenomenon of stress concentration in the composites, which increased the possibility of their failure. When the content of graphene increased to $2.5 \mathrm{wt} . \%$, the agglomeration of graphene accelerated the decrease of compressive strength of the composites. The results demonstrated that GDs could prevent the propagation of cracks, thus significantly improving the mechanical properties of the matrix. However, when the graphene content increased to some extent, the dispersion of graphene began to decrease obviously observed in the corresponding cross-section micro-morphology (Figure 3B-F), which led to the formation of cohesion and stress concentration, and increased the possibility of failure of the composite. On the other hand, Gao et $\mathrm{al}^{79}$ synthesized $\mathrm{B}_{4} \mathrm{C}$ composite ceramics with different graphene content from 0.4 wt.\% to $1.2 \mathrm{wt} . \%$ by pressureless sintering, and they found that with the increase of graphene content in the matrix, the mechanical properties of the composites increased at first and then decreased, and got to the biggest value when the graphene content was 0.8 wt.\% (Figure 3G). Most importantly, they found that different content of graphene led to two different reinforcing mechanisms. For example, the whole graphene layer would be pulled out when the composite with the graphene content of 0.4 wt.\% was broken (Figure $3 \mathrm{H}$ ). The fracture only needed to overcome the adhesion between graphene and $\mathrm{B}_{4} \mathrm{C}$ matrix. However, when the graphene content is $0.8 \mathrm{wt} . \%$, the fracture first occurred in the outermost layer of graphene, and then the inner layer of graphene was pulled out (Figure 3I). The fracture needed to overcome both the resistance of graphene and the bonding force between graphene and $\mathrm{B}_{4} \mathrm{C}$ matrix, thus absorbing more fracture energy and preventing crack propagation. As shown in Figure $3 \mathrm{G}$, with the increasing of graphene content, the porosity of the composites decreased at first and then increased. $\mathrm{B}_{4} \mathrm{C}$ substrate and graphene combined most closely when the graphene content was $0.8 \mathrm{wt} . \%$. When the graphene content was $1.0 \mathrm{wt} . \%$, isolated graphene sheets appeared in the interstice of grains, and this phenomenon was more serious when the graphene content was 1.2 wt.\%. So, it was indicated that the different addition content of graphene led to the different changes of the microstructure of the composites, which further led to different reinforcing mechanisms of the graphene, and thus affecting the final reinforcing effect.

Moreover, the functionalization of GDs could also significantly influence the reinforcing effect mainly from two aspects, one of which was that enhanced binding between GDs and matrix might be achieved after the functionalizations, ${ }^{81,82}$ and the other of which was that appropriate functionalizations could improve dispersion of GDs in the matrix, thereby getting better structural uniformity. ${ }^{83,84}$ For example, Ionita et $\mathrm{al}^{81}$ prepared porous polyvinyl alcohol Gel-polyvinyl alcohol (Gel-PVA) /GO materials for bone repair by freeze-drying method. Their subsequent results showed that addition of the GO could enhance the compressive strength of the material by $100 \%$. One of the main reasons to achieve such a satisfactory reinforcing effect might be that the covalent binding between -OH on the end group of $\mathrm{GO}$ and $\mathrm{COOH}$ on the PVA chain led to the helical recombination 

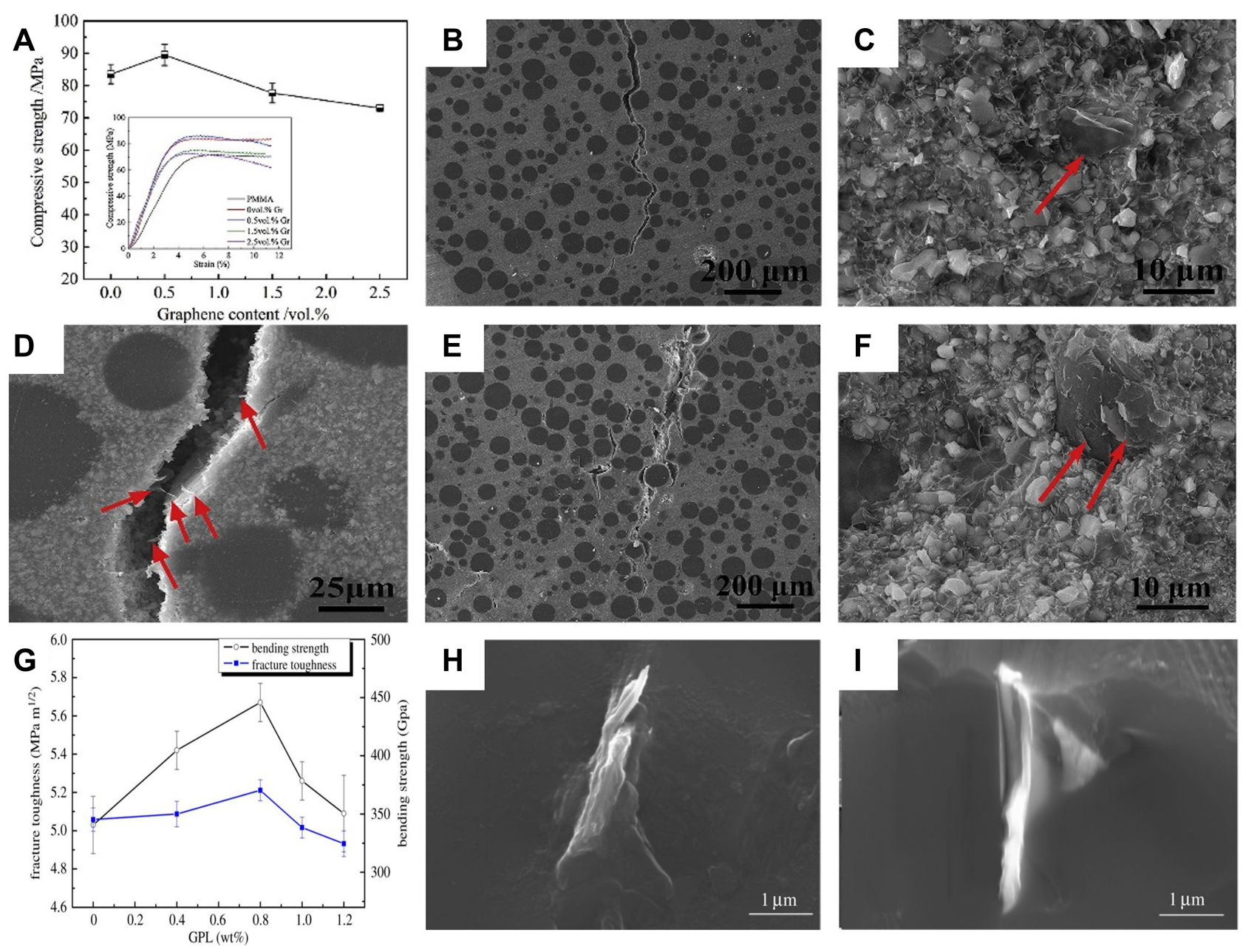

Figure 3 (A-F) Mechanical properties of graphene/barium titanate/polymethyl methacrylate composites with different graphene content: (A) compressive strength, in which the inset image showed the compressive strength curve of the composites, (B) crack propagation ( 0.5 wt.\% graphene), and (C) scanning electron microscope (SEM) images of fracture morphology ( 0.5 wt.\% graphene), in which red arrow indicated graphene, (D) SEM images of crack morphology ( $0.5 \mathrm{wt} \%$ graphene), in which the red arrow indicated graphene extracted during crack propagation, (E) SEM images of crack propagation (I.5 wt.\% graphene), and (F) SEM images of fracture morphology, in which red arrow showed graphene (I.5 wt.\% graphene); (G-I) Mechanical properties of B 4 $\mathrm{C}$ composite ceramics with different graphene content: $(\mathbf{G})$ effect of graphene addition on fracture toughness and bending strength of composites, $(\mathbf{H})$ SEM images of the fracture morphology of the composite with $0.4 \mathrm{wt} . \%$ graphene, which showed that the whole graphene layer was pulled out, and (I) SEM image of the fracture morphology of the composite with $0.8 \mathrm{wt} . \%$ graphene, which showed that the fracture of graphene first occurred in the outermost layer of graphene, and then the inner layer of graphene was pulled out. Reprinted from Ceramics International, Vol 45(5), Tang YF, Chen L, Duan ZH, Zhao K, Wu ZX, Graphene/barium titanate/polymethyl methacrylate bio-piezoelectric composites for biomedical application, Pages No.6567-6576, Copyright (2020), with permission from Elsevier (A-F). ${ }^{78}$ Reproduced from Gao DZ, Jing J, Yu JC, et al. Graphene platelets enhanced pressureless-sintered B4C ceramics. R Soc Open Sci. 20I8;5 (4): I7I837. (G-I). ${ }^{79}$

of the gel chain and improved the crystallinity of the PVA domain, which further led to more uniform structure in the composites. On the other hand, Zhang et $\mathrm{al}^{83}$ found that polydopamine functional reduced graphene oxide (PDA-rGO) had a significantly better reinforcing effect than GO in waterborne polyurethane (WPU) matrix mainly because polydopamine (PDA) on the surface of GO prevented the accumulation and aggregation of GO layers, resulting in the uniform dispersion of PDA-rGO in the WPU matrix, and the functional groups such as hydrophilic amine, imine and catechol on the surface of PDA-rGO could react with the -NCO group on the WPU molecular chain to form relatively strong covalent and hydrogen bonds, thus improving the load transfer efficiency from matrix to graphene sheet.

\section{Excellent Electrical Properties}

Current studies have shown that the improvement of electrical conductivity of bone repair materials is beneficial to enhance their osteogenic activities. ${ }^{85-87}$ Graphene possesses excellent electrical conductivity because its each carbon atom can form a $\pi$-bond structure with its neighboring carbon atoms on the pz orbital perpendicular to the monolayer plane and it has large SSA. ${ }^{88,89}$ The conductivity of graphene monolayer is up to $10^{4} \mathrm{~S} / \mathrm{cm}$, and the electron mobility is up to $15,000 \mathrm{~cm}^{2} /(\mathrm{V} \cdot \mathrm{s})$ at room temperature. ${ }^{90,91}$ 
In this subsection, the main utilization ways of excellent electrical conductivity of GDs in bone repair materials were summarized. One was to compound GDs with other materials to prepare $2 \mathrm{D} / 3 \mathrm{D}$ composites with satisfactory electrical conductivity, which could promote osteogenic activities of cells in vitro and bone formation in vivo under external electrical stimulation. GDs could be introduced into the matrix as an electrode to promote bone tissue regeneration under external electrical stimulation. Compared with traditional metal electrodes, graphene-containing composites had lower impedance and higher charge injection capacity. For example, Li et $\mathrm{al}^{92}$ prepared GDs-cellulose (G-C) scaffold and assembled an electrode device on this basis, which provided a platform for support and osteogenic differentiation of adipose-derived stem cell (ADSC). The results showed that the charge storage capacity of G-C electrode $\left(0.966 \mathrm{mC} / \mathrm{cm}^{2}\right)$ was higher than that of gold electrode $\left(0.462 \mathrm{mC} / \mathrm{cm}^{2}\right)$. Compared with the gold electrode, the G-C electrode showed lower impedance at low frequency $(0.1-150 \mathrm{~Hz})$, which indicated that it had higher energy efficiency and higher charge injection ability (Figure 4A and B). Furthermore, the results of in vitro experiments showed that the proliferation, mineral deposition and alkaline phosphatase (ALP) expression of adipose-derived stem cells (ADSCs) cultured with G-C electrode increased after electrical stimulation. Moreover, GO could be functionalized to further improve its electrical conductivity. ${ }^{94,95}$ For example, Jin et $\mathrm{al}^{94}$ introduced GO into the polyvinyl chloride/poly(lactic-co-glycolic acid) (PVC/PLGA) scaffold by electrospinning, and then GO-PVC/PLGA
A
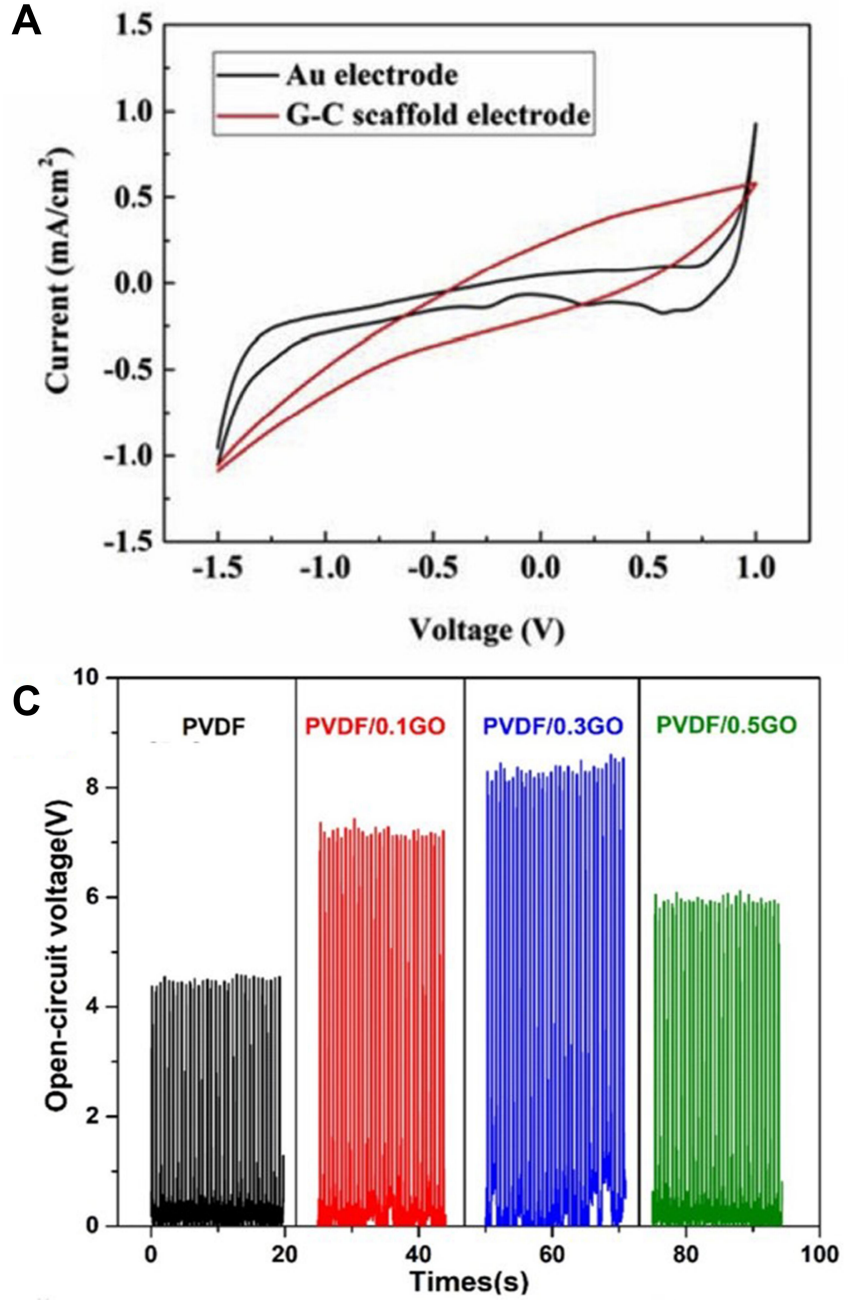

B
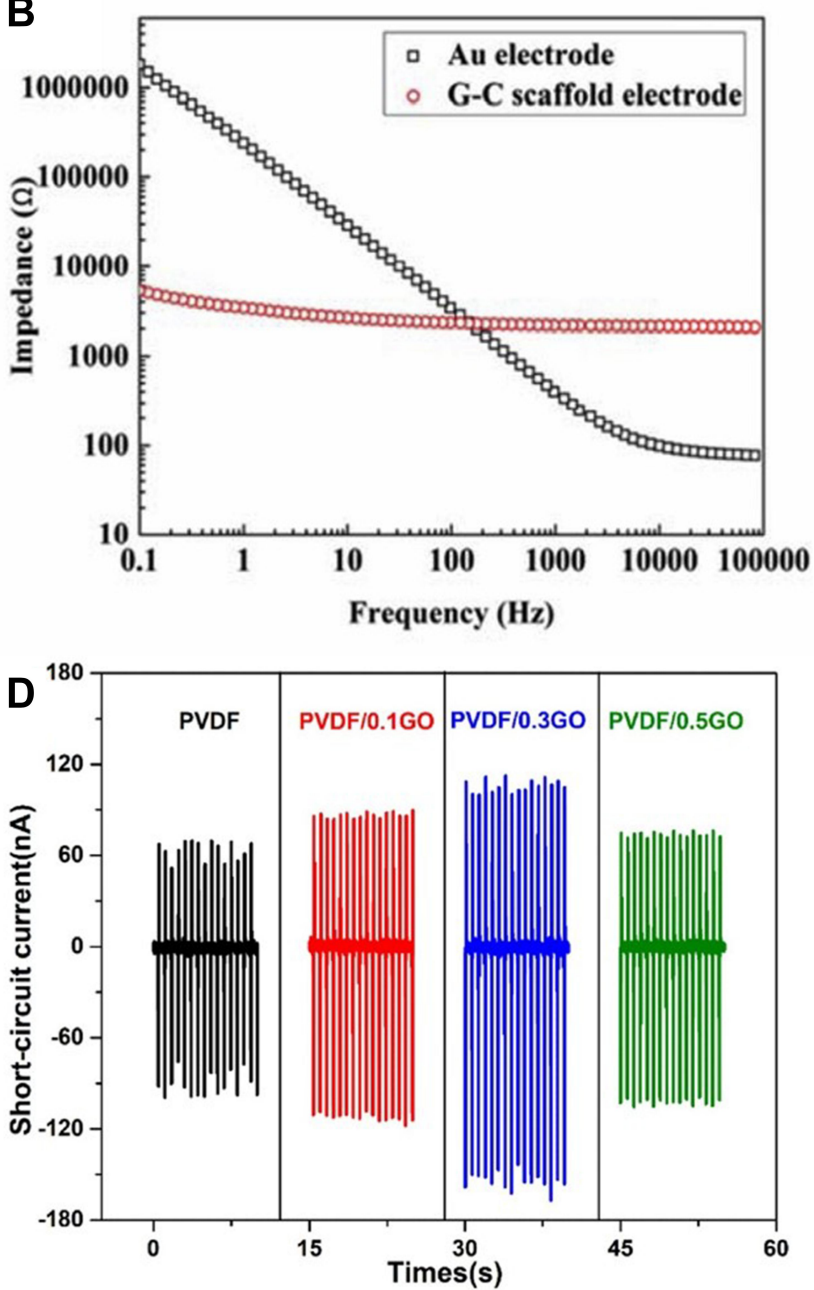

Figure 4 (A and B) Electrochemical characteristics of Au and graphene-cellulose scaffold electrodes: (A) cyclic voltammogram, and (B) electrochemical impedance spectroscopy (EIS); (C and D) Conductivity of polyvinylidene fluoride (PVDF)/GO composite scaffolds: (C) open-circuit voltage, and (D) short-circuit current. Reprinted from Materials Science and Engineering: C, Vol 107, Li JF, Liu X, Crook JM, Wallace GG, Electrical stimulation-induced osteogenesis of human adipose derived stem cells using a conductive graphene-cellulose scaffold, Pages No.I 103 I2, Copyright (2020), with permission from Elsevier (A and B). ${ }^{92}$ Reprinted from Materials \& Design, Vol I90, Shuai CJ, Zeng ZC, Yang YW, et al, Graphene oxide assists polyvinylidene fluoride scaffold to reconstruct electrical micro-environment of bone tissue, Pages No. 108564, Copyright (2020), with permission from Elsevier (C-D). ${ }^{96}$ 
composite scaffolds were immersed in hydrogen iodide solution to obtain rGO-PVC/PLGA scaffolds. The results showed that compared with GO-PVC/PLGA scaffolds, rGO-PVC/PLGA scaffolds had higher capacitance and better conductivity at a suitable voltage, which was due to the larger SSA of rGO-PVC/PLGA and the formation of more conjugated $\pi$-bonds on the surface of rGO. In another case, Silva et $\mathrm{al}^{95}$ introduced cyclic amine into graphene by 1.3-dipolar cycloaddition reaction, and then functionalized graphene was compounded with chitosan (CHI) and sodium alginate (ALG) to fabricate biofilms. The results showed that the introduction of functionalized graphene significantly reduced the resistivity of the thin films from $3.00 \times$ $10^{12} \Omega \mathrm{m}$ to $2.25 \times 10^{9} \Omega \mathrm{m}$.

The other method was to use the excellent electrical conductivity of GDs to improve the performances of piezoelectric biomaterials that could bring desired electrical stimulation for new bone formation under biomechanical environment in vivo. ${ }^{96,97}$ In addition to the excellent electrical conductivity of GDs themselves, GDs could also enhance the electrical output performance of the piezoelectric biomaterials by changing the phase structure of the matrix. For example, Shuai et $\mathrm{al}^{96}$ introduced GO into polyvinylidene fluoride (PVDF) to fabricate composite scaffolds for bone repair. The results showed that the open-circuit voltage and short-circuit current of the composite increased at first and then decreased with increasing of GO content. Compared with pure PVDF, the scaffold with 0.3 wt. $\%$ GO showed the best electrical output performance, and its maximum output voltage $(\sim 8.2 \mathrm{~V})$ and maximum current $(\sim 101.6 \mathrm{nA})$ were increased by $82.2 \%$ and $68.2 \%$, respectively (Figure $4 \mathrm{C}$ and $\mathrm{D}$ ). The main reason of which might be that there was a strong hydrogen bond between the oxygen-containing functional groups of GO and the fluorine groups of PVDF, which improved the interfacial bonding, and GO could induce the phase transition with higher energy conversion efficiency. However, when the content of GO was exorbitant, the electrical output capacity of the composites decreased, which might be due to the agglomeration of GO in the composites. Therefore, the content and dispersion of GDs could have a significant impact on the electrical output properties of the composites. Subsequently, in vitro experiments demonstrated that the introduction of GO could significantly promote the proliferation and ALP expression of MG-63 cells. The reason might be that GO had stronger electromechanical conversion ability, resulting in stronger electrical stimulation under the same external stress, and finally effectively promoting the behavior of cells.

\section{Large Specific Surface Area (SSA) and Easy Modification}

The large SSA of GDs could not only greatly improve cell adhesion, but also make GDs to be easily further functionalized and incorporated with other active materials to obtain bone repair materials with better performance. The functionalization of GDs could not only improve different properties in the matrix, but also used as a "bridge" for binding with active substances. ${ }^{98,99}$ On the other hand, GDs could be further endowed with new functions by binding with active substances. ${ }^{100-102}$

In this subsection, we reviewed the different functional groups of GDs modification in bone repair materials and the progress had been made in the properties and functions of the composites. Then, GDs were bound with different active substances such as peptides and drugs, and which functions of bone repair materials were improved by in vitro and in vivo experiments.

The common functional methods of GDs used in bone repair were carboxylation, ${ }^{103-105}$ silanization, ${ }^{106,107}$ hydroxylation, $^{25}$ dopamine modification $^{108,109}$ and amination, ${ }^{24,110}$ as shown in Table 1 . These functional modifications improved the different properties of the composites, such as binding other ions, dispersibility, hydrophilicity, adsorption of serum proteins and attraction to osteoblasts.

Firstly, the surface of GDs was negatively charged by carboxyl modification, which was more beneficial to improve the properties of the composites by combining cations. For example, Chen et $\mathrm{al}^{103}$ prepared carboxylated graphene oxide (GO-COOH) by $\mathrm{NaOH} / \mathrm{ClCH}_{2} \mathrm{COOH}$ and further covalently bound with $\mathrm{ZnO}$ (Figure 5A). The results showed that the surface of GO-COOH was negatively charged, which contributed to the stable bonding with $\mathrm{Zn}^{2+}$. Subsequently, the results of in vitro experiments showed that $\mathrm{ZnO} / \mathrm{GO}-\mathrm{COOH}$ composite significantly increased ALP activity, osteocalcin production and extracellular matrix mineralization in MG-63 cells. In addition, $\mathrm{ZnO} / \mathrm{GO}-$ $\mathrm{COOH}$ nanocomposites had a bacteriostatic effect on Streptococcus mutans.

Secondly, silanization improved the dispersion of GDs, resulting in stronger adhesion between GDs and the matrix after polymerization. Paz et al ${ }^{106}$ prepared the silylated graphene by (3-methacryloxypropyl) 
Table I Functionalization of GDs for Bone Repair

\begin{tabular}{|c|c|c|c|c|}
\hline Functionalization & Preparation Method & Properties & Functions & References \\
\hline Carboxylation & $\mathrm{NaOH} / \mathrm{ClCH}_{2} \mathrm{COOH}$ or $\mathrm{KMnO}_{4} / \mathrm{H}_{2} \mathrm{SO}_{4}$ & $\begin{array}{l}\text { Binding more positive amino } \\
\text { acids }\end{array}$ & $\begin{array}{l}\text { Improving mineralization } \\
\text { of MG63 cells }\end{array}$ & {$[103-105]$} \\
\hline Silanization & $\begin{array}{l}\text { Silane coupling method (hydrolysis, blending, } \\
\text { washing, freeze-drying) by } \\
\text { (3-methacryloxypropyl) trimethoxysilane } \\
\text { (MPS) }\end{array}$ & $\begin{array}{l}\text { Improving the dispersion of } \\
\text { graphene; } \\
\text { enhancing the compressive } \\
\text { strength and bending } \\
\text { strength of the materials }\end{array}$ & Lower cytotoxicity & {$[106,107]$} \\
\hline Hydroxylation & $\begin{array}{l}\text { I. } \mathrm{KMnO}_{4} / \mathrm{H}_{2} \mathrm{SO}_{4} \\
\text { 2.Sheared and emulsified in } \mathrm{NaOH}\end{array}$ & $\begin{array}{l}\text { Better mechanical property } \\
\text { and electrical conductivity }\end{array}$ & $\begin{array}{l}\text { Improving the } \\
\text { proliferation of rat } \\
\text { adipose stromal cells }\end{array}$ & [25] \\
\hline Dopamine & Chemical vapour deposition method & $\begin{array}{l}\text { Significantly improving the } \\
\text { binding ability and release } \\
\text { ability with BMP-2. }\end{array}$ & $\begin{array}{l}\text { Improving the exogenous } \\
\text { BMP2-induced } \\
\text { osteogenic differentiation }\end{array}$ & {$[108,109]$} \\
\hline Amination & $\begin{array}{l}\text { Sulfoxide chloride }\left(\mathrm{SOCl}_{2}\right) / \text { ethylene diamine/ } \\
\text { dimethylformamide (DMF) }\end{array}$ & $\begin{array}{l}\text { Better thermal stability and } \\
\text { higher mechanical } \\
\text { properties }\end{array}$ & $\begin{array}{l}\text { Stronger } \\
\text { osseointegration and } \\
\text { lower cytotoxicity }\end{array}$ & {$[24,110]$} \\
\hline
\end{tabular}

trimethoxysilane (MPS) and then introduced it into polymethyl methacrylate (PMMA) bone cement to prepare composite materials (Figure 5B). The results showed that the compressive strength, bending strength and fracture toughness of the composites containing silylated graphene were increased by $12 \%, 13.7 \%$ and $28 \%$, respectively, compared with those containing original graphene.

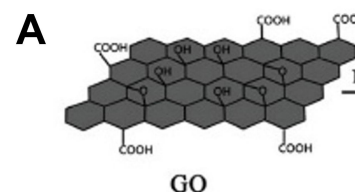

GO

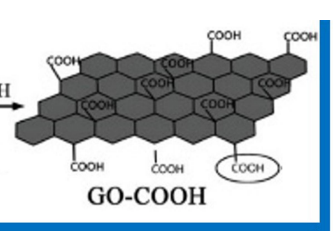

C

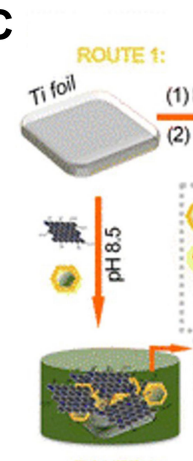

ROUTE 2:

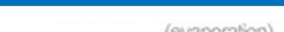

(evaporation)
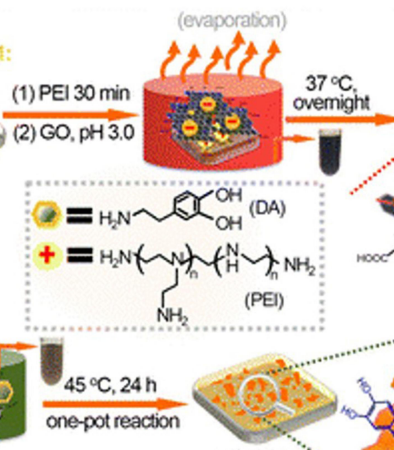

one-pot reaction
B
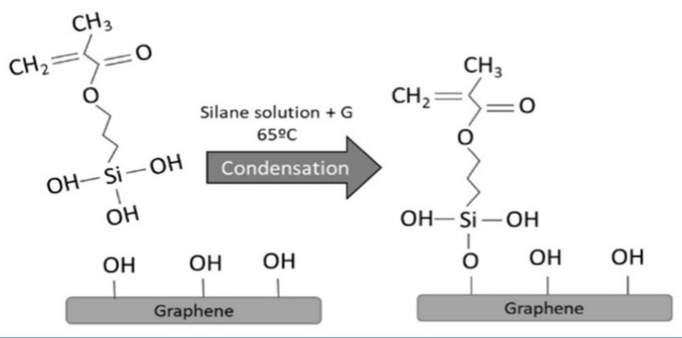

D

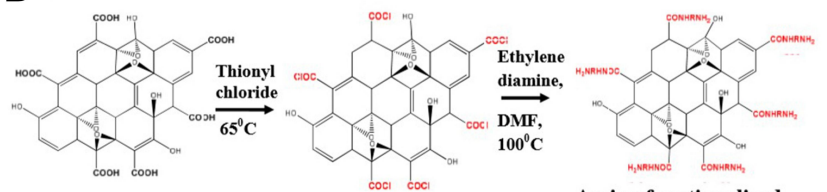

Graphene oxide

Graphene

Figure 5 Schematic diagram of GDs modified by various functional groups: (A) carboxylation, (B) silylation, (C) dopaminetization, and (D) amination. Reproduced with permission from Colloids and Surfaces B: Biointerfaces, Vol I47, Chen JY, Zhang X, Cai H, et al, Osteogenic activity and antibacterial effect of zinc oxide/carboxylated graphene oxide nano-composites: preparation and in vitro evaluation, Pages No.397-407, Copyright (2016), with permission from Elsevier (A). ${ }^{103}$ Reprinted from Materials Science and Engineering: C, Vol 104, Paz E, Ballesteros Y, Forriol F, Dunne NJ, Del Real JC, Graphene and graphene oxide functionalisation with silanes for advanced dispersion and reinforcement of PMMA-based bone cements, Pages No.109946, Copyright (2019), with permission from Elsevier (B)., ${ }^{106}$ Reprinted (adapted) with permission from Jia ZJ, Shi YY, Xiong P, et al. From solution to biointerface: graphene self-assemblies of varying lateral sizes and surface properties for biofilm control and osteodifferentiation. ACS Appl Mater Interfaces. 2016;8(27):17I5I-17I65. Copyright (2016) American Chemical Society (C). ${ }^{108}$ Reprinted (adapted) with permission from Sharma R, Kapusetti G, Bhong SY, et al. Osteoconductive amine functionalized graphene-poly(methylmethacrylate) bone cement composite with controlled exothermic polymerization. Bioconjugate Chem. 2017;28(9):2254-2265. Copyright (2017) American Chemical Society. (D) ${ }^{24}$ 
Thirdly, through hydroxylation modification, the surface of GDs was negatively charged, thus improving their hydrophilicity. Sun et $\mathrm{al}^{25}$ prepared hydroxylated graphene by two-step methods of $\mathrm{KMnO}_{4} / \mathrm{H}_{2} \mathrm{SO}_{4}$ and $\mathrm{NaOH}$ shear emulsification. In vitro experiments showed that the hydroxylation of graphene significantly promoted the proliferation of ADSCs. The hydrophilicity of hydroxylated graphene provided a better microenvironment for cell adhesion and proliferation.

Fourthly, dopamine modification could improve the adsorption of GDs to serum protein. The catechol groups on polydopamine (PDA) could covalently bind to the amino group on the protein through o-benzoquinoneamine coupling, promoting more serum proteins to be anchored to the surface of the composite, thus establishing a favorable extracellular matrix for rapid cell recruitment, stable adhesion and effective cytoskeleton construction. Jia et $\mathrm{al}^{108}$ covalently bound dopamine (DA) and GO by the method of evaporation-assisted electrostatic assembly to prepare rGO-PDA, and then rGO-PDA was introduced into titanium substrate to prepare composites (Figure 5C). In vitro experiments showed that rGO-PDA could significantly increase the adhesion, growth and ALP expression of MC3T3-E1 cells compared with GO.

Moreover, through amination, the positive charge was introduced on the surface of GDs, which increased the attraction of GDs to the negative charge of carboxylate and phosphate ions on the surface of the osteoblast membrane. Sharma et $\mathrm{al}^{24}$ synthesized amine-functionalized graphene by Sulfoxide chloride $\left(\mathrm{SOCl}_{2}\right)$ /Ethylene diamine/Dimethylformamide (DMF) and blended it with PMMA bone cement matrix to prepare bone cement composites (aminated graphene/PMMA) (Figure 5D). In vitro and in vivo experiments showed that compared with pure graphene and GO, the aminated graphene promoted the osseointegration of the composites and reduced its cytotoxicity, and the aminated graphene/PMMA composites were calcified earlier after implantation in rabbits.

On the basis of GDs functionalization, the binding with active molecules such as genes, ${ }^{111,112}$ peptides, ${ }^{26,113,114}$ activity factor ${ }^{115,116}$ and drugs ${ }^{117-119}$ contributed to the continuous release of active molecules, as shown in Table 2 . The active molecules could enhance a variety of functions of bone repair materials for a long period, such as proliferation, growth, osteogenic differentiation and antibacterial.

However, the mechanism and effect of functionalized GDs on different active molecules were different. The functionalized GDs were used as a carrier for gene transfection into cells, the charge on the surface of which was one of the most important factors affecting the transfection efficiency. For example, Liu et al ${ }^{111}$ blended graphene with oleic acid at first and then covalently bound them with polyamidoamine (PAMAM) to prepare graphene-oleatePAMAM composites. The results showed that the covalent modification of graphene by PAMAM greatly improved the transfection efficiency of green fluorescent protein gene (GFP). The transfection efficiency of grapheneoleate-PAMAM on HeLa cells was up to $18.3 \%$, which was 13 times that of GO. Because the primary amine group on the surface of PAMAM had a large amount of positive charge, graphene-oleate-PAMAM could effectively immobilize gene molecules and obtaining high transfection efficiency.

In another case, the improvement of the bioactivity of GDs-containing composites was not only due to the interaction between GDs and active molecules, but also related to the charge on the surface of the carrier. For example, Eckhart et $\mathrm{al}^{26}$ covalently bound polylysine with GO-COOH to prepare composites by acylation. The results showed that the covalent binding improved the electrical conductivity of the composites, which might be due to the strong interaction with the covalently bound peptides between the adjacent graphene layers, such as hydrogen bonding and chain entanglement, which led to the closeness between the graphene layers. On the contrary, the electrical conductivity of the composite prepared by non-covalent binding of peptide and GDs was lower than that of pure graphene, which might be due to the phase separation between peptide and GDs. The phase separation blocked the electron migration, so that it reduced the electrical conductivity of the composites. On the other hand, the terminal group of polylysine had a positive charge under the condition of physiological $\mathrm{pH}$, which was consistent with the principle that charge affects cell function. Therefore, these factors led to the enhancement of the adhesion of PC12 cells on the composites prepared by covalent binding.

Based on the above principle, including the interaction between GDs and active molecules, as well as the charge on the surface of the carrier, GDs binding with active molecules could promote stem cell proliferation, migration and differentiation. For example, Zhang et $\mathrm{al}^{115}$ introduced $\mathrm{Fe}^{3+}$ into GO through - $\mathrm{COOH}$ to prepare $\mathrm{GO}-\mathrm{Fe}_{3} \mathrm{O}_{4}$ magnetic nanoparticles through $\mathrm{FeCl}_{3} / \mathrm{NaOH}$ reaction. Then, BMP-2 was fixed to the nanoparticles, which enter the stem cells through endocytosis. The results showed that BMP-2 enhanced the proliferation, migration and 
Table 2 Application of GDs-Loaded Active Substance in Bone Repair

\begin{tabular}{|c|c|c|c|c|c|}
\hline $\begin{array}{l}\text { Types of } \\
\text { Active } \\
\text { Substance }\end{array}$ & $\begin{array}{l}\text { Examples of the } \\
\text { Active Substance }\end{array}$ & Preparation Method & Properties & Functions & References \\
\hline \multirow[t]{2}{*}{ Genes } & $\begin{array}{l}\text { Green fluorescent } \\
\text { protein gene (GFP) }\end{array}$ & $\begin{array}{l}\text { The PEGFP-NI plasmid containing GFP } \\
\text { gene was adsorbed on the surface of } \\
\text { graphene-oleic acid-polyamidoamine } \\
\text { (PAMAM) composites }\end{array}$ & $\begin{array}{l}\text { Good dispersion } \\
\text { and stability in } \\
\text { aqueous solutions }\end{array}$ & $\begin{array}{l}\text { Improving the efficiency of gene } \\
\text { transfection }\end{array}$ & {$[\mathrm{III}]$} \\
\hline & MiR-7b & $\begin{array}{l}\text { Blending of MiR-7b plasmid and GO-PEI } \\
\text { complex in aqueous solution to prepare } \\
\text { GO-PEl-miR-7b composites }\end{array}$ & I & $\begin{array}{l}\text { Excellent transfection efficiency in bone } \\
\text { marrow macrophages. Blocking the cell- } \\
\text { cell fusion of osteoclasts and promoting } \\
\text { bone regeneration. }\end{array}$ & {$\left[\begin{array}{lll}1 & 1 & 2\end{array}\right]$} \\
\hline \multirow[t]{3}{*}{ Peptides } & Polylysine & Self-assembled & Mechanically robust & $\begin{array}{l}\text { Enhancing adhesion and neurite } \\
\text { outgrowth of } \mathrm{PCI} 2 \text { cells }\end{array}$ & {$[26]$} \\
\hline & $\begin{array}{l}\text { Motif-specific peptide } \\
\text { (LLVFGAKMLPHHGA) }\end{array}$ & $\begin{array}{l}\text { The peptides were adsorbed on the } \\
\text { surface of the scaffolds by impregnation }\end{array}$ & $\begin{array}{l}\text { Adjustable shape, } \\
\text { superlow weight } \\
\text { and high porosity }\end{array}$ & Easy to mineralize & {$[\mathrm{I} \mid 3]$} \\
\hline & $\begin{array}{l}\text { Arginine-glycine- } \\
\text { aspartic acid (RGD) } \\
\text { peptide }\end{array}$ & $\begin{array}{l}\text { RGD peptides were self-assembled onto } \\
\text { the surface of GO/silica nanoparticles } \\
\text { composites on indium tin oxide (ITO) } \\
\text { substrates. }\end{array}$ & $\begin{array}{l}\text { Excellent electrical } \\
\text { conductivity }\end{array}$ & $\begin{array}{l}\text { Promoting osteogenic differentiation of } \\
\text { adipose-derived mesenchymal stem cells } \\
\text { (ADSCs) }\end{array}$ & {$[114]$} \\
\hline \multirow[t]{2}{*}{$\begin{array}{l}\text { Activity } \\
\text { factors }\end{array}$} & $\begin{array}{l}\text { Bone-morphogenetic- } \\
\text { protein-2 (BMP-2) }\end{array}$ & $\begin{array}{l}\text { The BMP- } 2 \text { factor was adsorbed on the } \\
\text { surface of } \mathrm{GO}-\mathrm{Fe}_{3} \mathrm{O}_{4} \text { nanoparticles by } \\
\text { impregnation. }\end{array}$ & l & $\begin{array}{l}\text { Promoting osteogenic differentiation of } \\
\text { dental pulp stem cells (DPSCs) }\end{array}$ & [115] \\
\hline & $\begin{array}{l}\text { Human recombinant } \\
\text { bone morphogenetic } \\
\text { protein-2 (rhBMP-2) }\end{array}$ & $\begin{array}{l}\text { The rhBMP-2 factor was adsorbed on } \\
\text { the surface of heparin modified } \\
\text { graphene scaffold by impregnation. }\end{array}$ & $\begin{array}{l}\text { Significantly } \\
\text { prolonged the } \\
\text { release of factors. }\end{array}$ & $\begin{array}{l}\text { Promoting osteoblast differentiation of } \\
\mathrm{C} 2 \mathrm{Cl} 2 \text { cells }\end{array}$ & {$[116]$} \\
\hline \multirow[t]{3}{*}{ Drugs } & Simvastatin (SV) & $\begin{array}{l}\text { SV was crosslinked with graphene } \\
\text { oxide-chitosan-hyaluronic acid } \\
\text { composite scaffold by EDC/NHS } \\
\text { method. }\end{array}$ & $\begin{array}{l}\text { Higher mechanical } \\
\text { support for } \\
\text { scaffolds }\end{array}$ & $\begin{array}{l}\text { Higher mineralization activity of } \mathrm{MC} 3 \mathrm{~T} 3 \\
\text { cells }\end{array}$ & {$[117]$} \\
\hline & $\begin{array}{l}\text { Dexamethasone } \\
(\mathrm{DEX})\end{array}$ & $\begin{array}{l}\text { DEX was used to prepare DEX- } \\
\text { phosphate monoester-GO-chitosan } \\
\text { composite scaffold by covalent bonding } \\
\text { of phosphate ester bond. }\end{array}$ & $\begin{array}{l}\text { A sustaining release } \\
\text { for longtime in } \\
\text { scaffolds in different } \\
\mathrm{pH} \text { conditions. }\end{array}$ & Excellent biocompatibility & {$[118]$} \\
\hline & Vancomycin (VA) & $\begin{array}{l}\text { VA was adsorbed on the surface of } \\
\text { rGO-nano hydroxyapatite composite } \\
\text { scaffold by impregnation. }\end{array}$ & $\begin{array}{l}\text { Persistent pathogen } \\
\text { resuscitation } \\
\text { inhibition }\end{array}$ & $\begin{array}{l}\text { Improving cell adhesion and osteogenic } \\
\text { differentiation of Bone marrow } \\
\text { mesenchymal stem cells (BMSCs) }\end{array}$ & {$[119]$} \\
\hline
\end{tabular}

differentiation of dental pulp stem cell (DPSCs) into osteoblasts around the cell membrane to form the new bone. Compared with traditional $\mathrm{Fe}_{3} \mathrm{O}_{4}$ nanoparticles, $\mathrm{GO}$ provided many carboxyl groups that could bind to growth factors. With the help of the magnetic nanoparticles, BMP-2 was integrated into cells and induced into the bone.

In addition, covalent binding was conducive to the continuous release of active molecules, so it could maximize the function of active molecules. For example,
Unnithan et $\mathrm{al}^{117}$ crosslinked simvastatin (SV) with GO by EDC, and then introduced them into chitosan (CS) and hydroxyapatite (HA) to prepare SV-GO-CS-HA composite scaffolds. The release curve of SV showed that drugs could be released from CS-HA-GO scaffolds in a controlled manner, and the drug loading rates of $0.5 \%$ and $1 \%$ SV-loaded on GO-CS-HA scaffolds were $68 \%$ and $82 \%$, respectively. In vitro experiments showed that SV significantly enhanced the osteogenic and biomineralization ability of MC3T3 cells. Moreover, GO initiated the 
effective interaction between the scaffolds and mineral ions through the existence of functional groups such as $\mathrm{COOH},-\mathrm{OH}$ and epoxy groups on the scaffold surface, thus promoting the formation of HA particles.

\section{Improving Functions of Bone-Related Cells in vitro and Bone Regeneration in vivo}

GDs had been considered as the next generation of bioactive nanomaterials, which could not only significantly improve the functions of bone-related cells such as adhesion, proliferation, osteogenic differentiation and mineralization in vitro, but also promote bone regeneration in vivo.

Many in vitro experiments showed that introducing a small amount of GDs into substrates could significantly improve the related functions of osteoblasts such as adhesion and proliferation. ${ }^{120-122}$ For example, Liang et al ${ }^{120}$ prepared nano-hydroxyapatite/poly(lactic-co-glycolic acid)/graphene oxide (nHAC/PLGA/GO) threedimensional porous scaffolds by freeze-drying, then cocultured them with MC3T3-E1 cells. The results showed that $\mathrm{nHAC} / \mathrm{PLGA} / \mathrm{GO}$ (1.5 wt.\%) scaffold could promote the adhesion and proliferation of osteoblast (MC3T3-E1) more significantly than nHAC/PLGA scaffold at days 3, 5, and 7 , and that the cells were larger and more stretched. In another case, $\mathrm{Li}$ et $\mathrm{al}^{121}$ prepared rGO coating on the surface of Ti6Al4V alloy and studied the effect of rGO coating on the growth and osteogenic differentiation of MC3T3-E1 cells, the results of which showed that the rGO coating significantly promoted the growth and osteogenic differentiation of MC3T3-E1 cells on Ti6A14V implants at days 3 and 7 . In addition, the quantitative reverse transcription-polymerase chain reaction (RT$\mathrm{qPCR}$ ) results demonstrated that bone sialoprotein (BSP), osteocalcin $(\mathrm{OCN})$ and runt-related transcription factor 2 (Runx2) expressions of the cells cultured on the rGOcoated substrate at day 7 were significantly higher than those of the cells cultured on the original Ti6Al4V substrate $(\mathrm{p}<0.05)$.

Moreover, GDs could regulate the osteogenic differentiation of stem cells from different sources because they could provide stem cells with a unique physical framework comparable to natural extracellular matrix (ECM). ${ }^{123-125}$ For example, Newby et al ${ }^{123}$ prepared GO nanoparticles with oxygen content of 6-10\%, then co-cultured them with human mesenchymal stem cells (MSCs), and evaluated the effect of graphene nanoparticles on osteogenic differentiation of these stem cells by alizarin red staining and quantitative analysis. The results showed that the calcium content of MSCs co-cultured with GO nanoparticles was significantly higher than that of cells on the control surface. Interestingly, the up-regulation was observed in the absence of any osteoinductive agents (dexamethasone, $\beta$ glycerophosphate or ascorbic acid), which indicated that GO nanoparticles could spontaneously induce calcium accumulation in MSCs. In another case, Krukiewicz et $\mathrm{al}^{124}$ prepared GO/PMMA composites by pressing machine and artificial smearing, respectively. Then, the osteogenic differentiation efficiency of human primary mesenchymal stem and progenitor cells (hMSPCs) cultured on GO/PMMA composite was studied by three differentiation markers, namely ALP, secreted protein acidic and rich in cysteine (SPARC), and bone morphogenetic protein-2 (BMP-2), the results of which showed that both GO/PMMA composites were effective in inducing osteogenic differentiation and were superior to unmodified PMMA. Moreover, the GO/ PMMA composite prepared by artificial smear had the highest efficiency of inducing osteogenic differentiation of the cells, which might be due to a large number of voids and pores on its surface.

On the other hand, in vivo experiments on various animal models showed that GDs could not only promote bone repair but also significantly enhance ectopic bone formation, indicating the great potential of GDs as bone repair material. ${ }^{126-129}$ For example, Zou et al ${ }^{126}$ prepared graphene and Laponite (GL) composite nanoparticles, then mixed the nanoparticles with MSCs infected with recombinant adenovirus-bone morphogenetic protein-9 (AdBMP9), and implanted the mixture under the skin of athymic nude mice. The results showed that graphenecontaining composite nanoparticles could significantly enhance BMP9-induced ectopic bone formation from MSCs than pure GL nanoparticles. In another case, Nie et $\mathrm{al}^{127}$ prepared 3D porous rGO composites by selfassembly of GO and nHA and then constructed biomimetic scaffolds by freeze-drying to repair bone defects. In vivo experiments showed that after 6 weeks of implantation, the porous scaffold containing rGO successfully cured rabbits round skull defect with a diameter of $4 \mathrm{~mm}$, which was faster than that of pure nHA scaffolds. Computed tomography (CT) and histological analysis showed that the introduction of rGO could significantly 
improve the collagen deposition, cell proliferation and new bone formation in the defect model than nHA scaffolds.

\section{Composites with Different Substrates for Bone Repair Materials}

GDs could be introduced into different kinds of substrates, such as metals, ${ }^{130-132}$ inorganic nonmetals, ${ }^{133-136}$ natural polymers $^{137-139}$ and synthetic polymers ${ }^{140-143}$ to prepare bone repair materials with improved performance, as shown in Table 3. In this subsection, the updated progress on research and development of those materials was reviewed. Especially, the functions of GDs themselves and the synergistic effects with other materials in vitro and in vivo were emphasized.

GDs played a very important role in the preparation and development of load-bearing bone materials with excellent functions. ${ }^{130-132}$ Metal substrate provided hard mechanical support for load-bearing bone materials, but it also had the problems of fast corrosion rate, stress shielding and low bioactivity. Therefore, GDs with the excellent properties were used to improve the in vitro/in vivo function of the composites, and the synergistic effect of GDs and substrate provided a good microenvironment for further improving the performances of the composites.

In the past, GDs were mostly introduced into the metal substrates in the form of coatings. However, in order to obtain the microstructure closer to the natural bone, GDs were introduced into the metal substrate to prepare a three-dimensional structure. For example, Qiu et $\mathrm{al}^{130}$ introduced $\mathrm{GO}$ into titanium substrates treated by $\mathrm{NaOH} /$ 3-aminopropyltrimethoxysilane (APS) method. Subsequently, GO was reduced to rGO by alkaline thermal method to prepare three-dimensional porous nanocomposites. The results showed that nanocomposites could promote ALP activity, extracellular matrix (ECM) mineralization and collagen secretion of rat bone marrow mesenchymal stem cells (rBMSCs). Moreover, the expression of osteogenesis-related genes such as ALP, bone morphogenetic protein-2 (BMP-2), osteocalcin $(\mathrm{OCN})$ and osteopontin (OPN) increased on the surface of nanocomposites. The improvement of function might be attributed to the unique three-dimensional structure formed through the cross-linking of silanol-based $(\mathrm{SiOH})$ introduced on the surface of titanium substrate, which affected the interactions of cell-cell and cellmaterial. Furthermore, the reduction of $\mathrm{GO}$ to $\mathrm{rGO}$ resulted in more aromatic structures on the surface of the composites, which have a strong non-covalent interaction with biomolecules.

In another case, Lyu et $\mathrm{al}^{131}$ constructed layered $\mathrm{ZnO}$ nanotubes/silk fibroin/graphene oxide nanostructures (SF/GO$\mathrm{ZnO}$ ) on pure zinc substrates by anodizing and $\mathrm{SF} / \mathrm{GO}$ selfassembly. Subsequently, SF/GO-Dex-ZnO was prepared by coating the osteogenic drug dexamethasone (Dex) to further improve the function of the composites. The results showed that $\mathrm{SF} / \mathrm{GO}-\mathrm{Dex}-\mathrm{ZnO}$ had excellent bactericidal and osteogenic activity, which might be due to the unique structure of GO and the active oxygen produced during the degradation of $\mathrm{ZnO}$. Among them, the "sharp" of GO nanosheet structure destroyed the cell membrane of bacteria through direct mechanical contact with bacteria. In addition, on the composite with SF/GO coating, the cells stretched in different directions, while the cells on the pure zinc and the cells on anodized zinc were elongated, which showed that $\mathrm{SF} / \mathrm{GO}$ coating had a positive effect on promoting cell proliferation. The reason for the above results might be that the composition of SF was similar to that of collagen, the main component of extracellular matrix, and GO had a higher adsorption capacity for serum protein, resulting in a higher density of adhesion molecules could be used for cell adhesion and growth. Therefore, SF and GO jointly promoted the early diffusion and proliferation of cells.

In the composition of bone, inorganic substances such as hydroxyapatite accounted for a large proportion, so whether it could stimulate the biomineralization of inorganic substances in natural bone was regarded as an important index in the process of bone repair. ${ }^{133-136}$ In the past, inorganic/organic composite scaffolds based on polymers were a common choice for bone repair, but the agglomeration of inorganic particles affected their overall stability and bioactivity. Therefore, the introduction of GDs could solve the problems. For example, Zhao et al ${ }^{133}$ prepared GO/ chitosan/nano-hydroxyapatite particles (GO/CS/nHAP) scaffolds by introducing nHAP into $\mathrm{CS}$ and GO covalent binding network matrix by in situ one-step bionic technology. The scaffolds had excellent physical and chemical properties, such as threedimensional porous bone structure, mechanical properties, biodegradability and water absorption. Furthermore, in vitro experiments demonstrated that compared with the defect in CS/nHAP group, the defect in GO/CS/nHAP group was almost filled with new bone tissue and formed a complete structure with the natural bone, the reasons for which included the following aspects. Firstly, the network substrate of $\mathrm{GO} / \mathrm{CS}$ effectively regulated the uniform dispersion of nHAP on the nanometer scale and promoted the formation of bone-like organic-inorganic hybrid structure. Secondly, the covalent binding of $\mathrm{GO} / \mathrm{CS}$ strengthened 
Table 3 GDs-Containing Composites and Their Application in Bone Repair

\begin{tabular}{|c|c|c|c|c|c|c|}
\hline $\begin{array}{l}\text { Types of } \\
\text { Substrates }\end{array}$ & Examples & Preparation Method & Structure & Properties & Functions & References \\
\hline \multirow[t]{3}{*}{ Metal } & Titanium & $\begin{array}{l}\text { Silane coupling using } \mathrm{NaOH} / \\
\text { APS }\end{array}$ & 3D porous nanosheets & $\begin{array}{l}\text { Super hydrophilic, } \\
\text { rough surface }\end{array}$ & $\begin{array}{l}\text { Promoting ALP activity, } \\
\text { ECM mineralization } \\
\text { and collagen secretion } \\
\text { of BMSCs }\end{array}$ & {$[130]$} \\
\hline & Zinc & $\begin{array}{l}\text { SF/GO was self-assembled } \\
\text { and coated on anodized zinc } \\
\text { substrate }\end{array}$ & $\begin{array}{l}\text { The GO coating was } \\
\text { attached to the } \mathrm{Zn} \text { surface } \\
\text { where many } \mathrm{ZnO} \text { nanotubes } \\
\text { were formed. }\end{array}$ & I & $\begin{array}{l}\text { Excellent bactericidal } \\
\text { activity and osteogenic } \\
\text { activity }\end{array}$ & {$[13 \mid]$} \\
\hline & Magnesium & $\begin{array}{l}\text { Mg powder and } 0.1 \text { wt } \% \\
\text { graphene nanosheets were } \\
\text { dispersed by ball mill and } \\
\text { then sintered. }\end{array}$ & Micron particles & $\begin{array}{l}\text { Improving hardness } \\
\text { and corrosion } \\
\text { resistance }\end{array}$ & 1 & [132] \\
\hline \multirow[t]{4}{*}{$\begin{array}{l}\text { Inorganic } \\
\text { substance }\end{array}$} & Hydroxyapatite & $\begin{array}{l}\text { Preparation of GO/chitosan/ } \\
\text { nHAP by in-situ synthesis } \\
\text { and microwave-assisted } \\
\text { method }\end{array}$ & 3D porous scaffold & $\begin{array}{l}\text { Better dispersion and } \\
\text { remarkable strength }\end{array}$ & $\begin{array}{l}\text { Significantly improving } \\
\text { MC3T3-EI cells } \\
\text { viability }\end{array}$ & {$[133]$} \\
\hline & $\begin{array}{l}\text { Calcium } \\
\text { phosphate }\end{array}$ & $\begin{array}{l}\text { Liquid-phase and powder- } \\
\text { phase mixing }\end{array}$ & Rough microporous & $\begin{array}{l}\text { Higher stability, } \\
\text { injectability and } \\
\text { rheology }\end{array}$ & $\begin{array}{l}\text { Increasing the survival } \\
\text { rate of BMSCs slightly }\end{array}$ & {$[134]$} \\
\hline & Calcium carbonate & $\begin{array}{l}\mathrm{CaCl}_{2} / \mathrm{rGO} \text { and } \mathrm{Na}_{2} \mathrm{CO}_{3} \\
\text { aqueous solution reaction }\end{array}$ & Hollow microsphere & $\begin{array}{l}\text { Sensitive release } \\
\text { characteristics of } \mathrm{pH}\end{array}$ & No cytotoxicity & {$[135]$} \\
\hline & Tricalcium silicate & $\begin{array}{l}\text { Liquid-phase and powder- } \\
\text { phase mixing }\end{array}$ & $\begin{array}{l}\text { Spherical particles with } \\
\text { rough and porous surface }\end{array}$ & $\begin{array}{l}\text { Higher compressive } \\
\text { strength and lower } \\
\mathrm{pH} \text { value }\end{array}$ & $\begin{array}{l}\text { Excellent ability of } \\
\text { MC3T3-EI cells } \\
\text { proliferation and } \\
\text { antibacterial }\end{array}$ & {$[136]$} \\
\hline \multirow[t]{3}{*}{$\begin{array}{l}\text { Natural } \\
\text { polymer }\end{array}$} & Chitosan & $\begin{array}{l}\text { In situ crystallization } \\
\text { process (acetic acid, } \mathrm{Ca} \\
\left(\mathrm{NO}_{3}\right)_{2} \text { and } \mathrm{K}_{2} \mathrm{HPO}_{4} \\
\text { aqueous solution) }\end{array}$ & $\begin{array}{l}\text { 3D porous bone-like } \\
\text { hierarchical structure }\end{array}$ & $\begin{array}{l}\text { Biodegradability and } \\
\text { appropriate water } \\
\text { absorption and water } \\
\text { retention }\end{array}$ & $\begin{array}{l}\text { Excellent biological } \\
\text { activity and ability to } \\
\text { induce bone } \\
\text { regeneration in situ }\end{array}$ & [137] \\
\hline & Cellulose & $\begin{array}{l}\text { Dispersion deposition- } \\
\text { drying }\end{array}$ & $\begin{array}{l}\text { GO-coated cellulose tissue } \\
\text { paper }\end{array}$ & $\begin{array}{l}\text { Lower impedance } \\
\text { and higher charge } \\
\text { injection capacity }\end{array}$ & $\begin{array}{l}\text { Promoting the } \\
\text { proliferation and } \\
\text { osteogenic } \\
\text { differentiation of ADSCs }\end{array}$ & {$[138]$} \\
\hline & Collagen & Sol-gel method & $\begin{array}{l}\text { Highly porous and } \\
\text { interconnected aerogels }\end{array}$ & $\begin{array}{l}\text { Excellent } \\
\text { hydrophilicity and } \\
\text { improving } \\
\text { compression modulus }\end{array}$ & $\begin{array}{l}\text { Better } \\
\text { biomineralization and } \\
\text { cytocompatibility }\end{array}$ & [139] \\
\hline \multirow[t]{4}{*}{$\begin{array}{l}\text { Synthetic } \\
\text { polymer }\end{array}$} & $\begin{array}{l}\text { Polycaprolactone } \\
\text { (PCL) }\end{array}$ & 3D printing & $3 D$ porous structures & $\begin{array}{l}\text { Significantly higher } \\
\text { electrical } \\
\text { conductivity }\end{array}$ & $\begin{array}{l}\text { Higher mineralization } \\
\text { nucleation rate in vitro }\end{array}$ & {$[140]$} \\
\hline & $\begin{array}{l}\text { Polyethyleneimine } \\
\text { (PEI) }\end{array}$ & $\begin{array}{l}\text { PEI were crosslinked with } \\
\text { GO by EDC/NHS. }\end{array}$ & Nanofillers & $\begin{array}{l}\text { Improving the } \\
\text { ultimate tensile } \\
\text { strength and elastic } \\
\text { modulus }\end{array}$ & $\begin{array}{l}\text { Promoting the effective } \\
\text { interfacial adhesion and } \\
\text { compatibility with the } \\
\text { matrix }\end{array}$ & {$[|4|]$} \\
\hline & Polyurethane (PU) & $\begin{array}{l}\text { UV crosslinking using 3D } \\
\text { printing technology }\end{array}$ & 3D porous structures & $\begin{array}{l}\text { Better tensile } \\
\text { strength and bending } \\
\text { strength }\end{array}$ & 1 & {$[142]$} \\
\hline & $\begin{array}{l}\text { Polylactic acid } \\
\text { (PLA) }\end{array}$ & Electrospinning & Nanocomposite fiber & $\begin{array}{l}\text { Increasing tensile } \\
\text { strength and } \\
\text { modulus of elasticity }\end{array}$ & $\begin{array}{l}\text { Promoting Saos-2 cells } \\
\text { proliferation }\end{array}$ & {$[143]$} \\
\hline
\end{tabular}


the interfacial interaction between organic and inorganic materials, and it enhanced the stability of GO/CS/nHAP scaffolds in the degradation process. Thirdly, the sheet structure of GO maintained a certain space between the composite fiber units and improved the hydrophilicity of GO/CS/nHAP scaffolds. Finally, the abundant functional groups on GO (such as $\mathrm{COOH},-\mathrm{OH}$ and epoxy groups) and $\mathrm{CS}$ (such as $-\mathrm{NH}_{2}$ ) promoted the in situ recruitment, proliferation and differentiation of endogenous stem cells at the injured site, thus realizing endogenous bone tissue regeneration.

Polymers had been widely used as bone repair materials because of its many advantages, such as easy to prepare into three-dimensional porous structure, degradability and similar mechanical properties to the implanted tissue. However, many pure polymers such as poly (caprolactone) (PCL), polylactic acid (PLA) were hydrophobic solids and lacked functional groups, resulting in low cellular response. GDs could be uniformly dispersed into the polymer matrix by membrane lamination, fiber bonding, 3D printing and other methods to make up for these shortcomings. For example, Unagolla et $\mathrm{al}^{140}$ prepared PCL-GO composite scaffolds by 3D printing, which could independently control the size and pore diameter of the implants. The morphology observation showed that the surface of the pure PCL scaffold was rough and irregular, while the surface of the scaffold containing GO was smooth and there were GO particles on the surface, which indicated that the introduction of GO improved the fluidity of the composites. The ALP activity assay confirmed that GO increased ALP activity of composite scaffolds (Figure 6A). Subsequently, as shown in Figure 6B and C, the calcium and phosphorus analysis showed that compared with simple PCL scaffolds, GO promoted the mineralization of scaffolds. The reason of which might be that the functional groups and electrical conductivity of GO improved the function of the composites. Furthermore, Western blot analysis demonstrated that the porous structure of GO and PCL composite scaffolds promoted the secretion of bone morphogenetic protein-2 and osteopontin, thus stimulating its osteogenesis.

\section{Mechanism of GDs-Induced Bone Regeneration Possible Signaling Pathways Involved in GDs-Induced Osteogenic Differentiation of Stem Cells}

The important index to evaluate the performance of bone repair material was whether it could recruit reactive osteoblast progenitor cells and eventually differentiate into osteocytes in the process of bone regeneration. Stem cells from different sources could be used as progenitor cells in the process of bone formation, so their recruitment and osteogenic differentiation were key factors for effective bone regeneration. GDs were proved to have the ability of osteogenic induction, ${ }^{144-152}$ as shown in Table 4. In this subsection, the signaling pathways involved in GDs-induced bone regeneration were discussed, including which signaling pathways of osteogenic differentiation of stem cells from different sources were affected by GDs and the effect of GDsrelated parameters on the signaling pathway.

Currently, different types of stem cells were studied, including bone marrow mesenchymal stem cells (BMSCs), adipose-derived stem cells (ADSCs), stem cells from human exfoliated deciduous teeth (SHEDs) and tonsilderived mesenchymal stem cells (TMSCs). Cytobiological assay and Ribonucleic Acid (RNA) sequencing were used to evaluate the signaling pathway of GDs-induced stem cells to differentiate into osteoblasts. These studies were systematically summarized in Table 4, and some possible rules were found.

Firstly, when GDs were used alone and GDs were combined with other materials, the signaling pathways involved in GDs-induced bone regeneration were different, which might be due to the change of the surface charge and groups after GDs were introduced into the matrix. For example, Qi et $\mathrm{al}^{144}$ prepared sericin methacryloyl/GO (SMH/GO) composite hydrogel as bone repair material by photo-crosslinking. The results of in vivo experiments showed that the hydrogel containing GO had a better bone regeneration effect, and the structure and function of rat skull defect model were repaired within 12 weeks. Subsequently, the results of cytobiological assay and RNA sequencing showed that the expressions of key genes related to bone marrow mesenchymal stem cell migration (such as Bmp6, Tgf- $\beta 1$, Mmp2, Mmp3, Mmp8, Mmp10 and Mmp12) and osteogenic differentiation-related genes (such as Tgf- $\beta 1$, Smad1, Bmp6, Fgf7, Mapk3, Mapk6 and Gs3k) were the highest in SMH/GO hydrogel group. The up-regulated expression of these genes indicated that $\mathrm{SMH} / \mathrm{GO}$ hydrogel might promote the migration and osteogenic differentiation of BMSCs by regulating biological processes such as "positive regulation of cell migration", "positive regulation of osteoblast differentiation" and "positive regulation of myeloid cell differentiation". Moreover, through signaling pathway analysis, they revealed the possible mechanism of bone regeneration, $\mathrm{SMH} / \mathrm{GO}$ hydrogel regulated the migration and osteogenic 
A

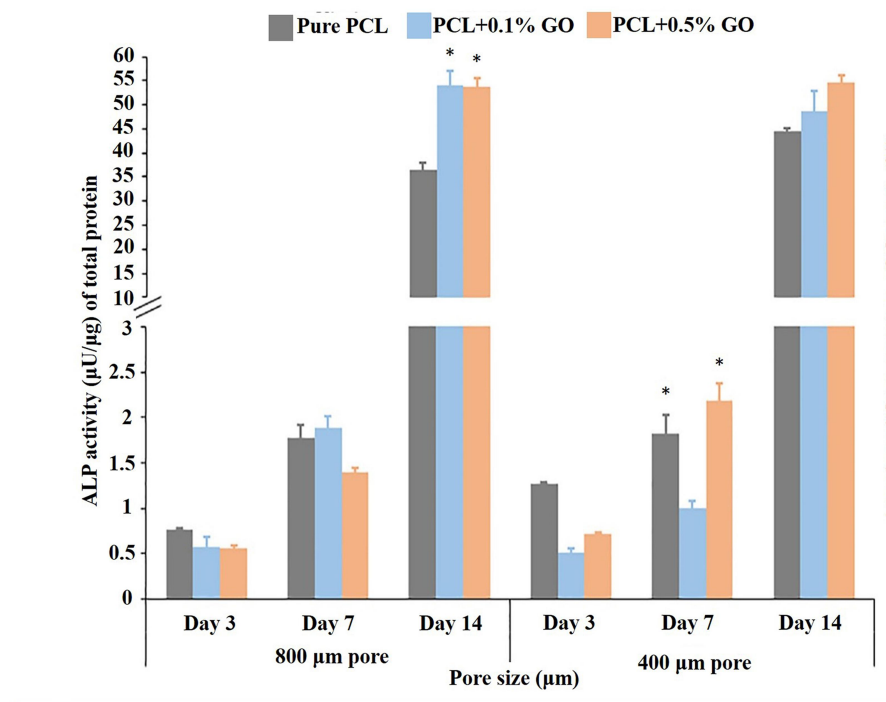

B

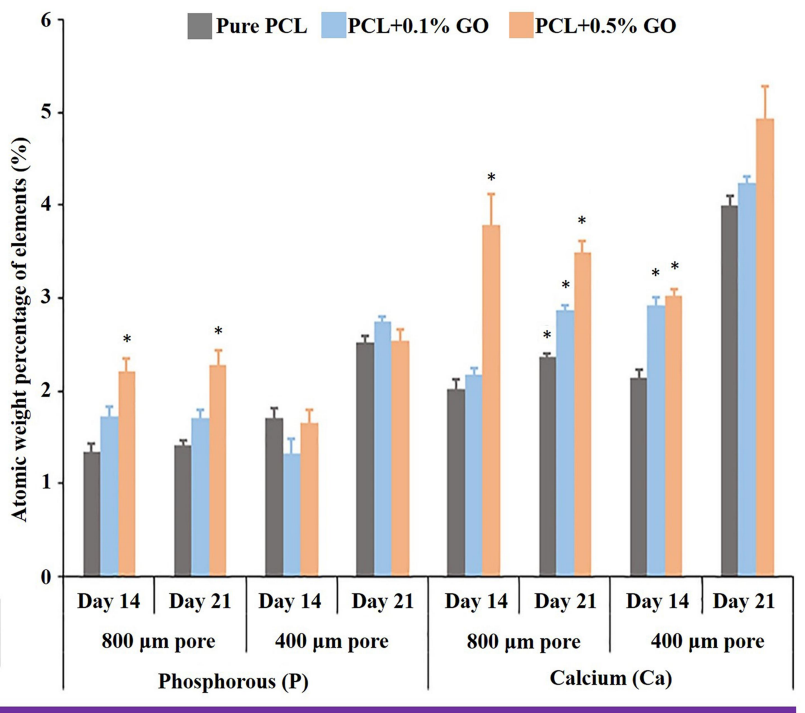

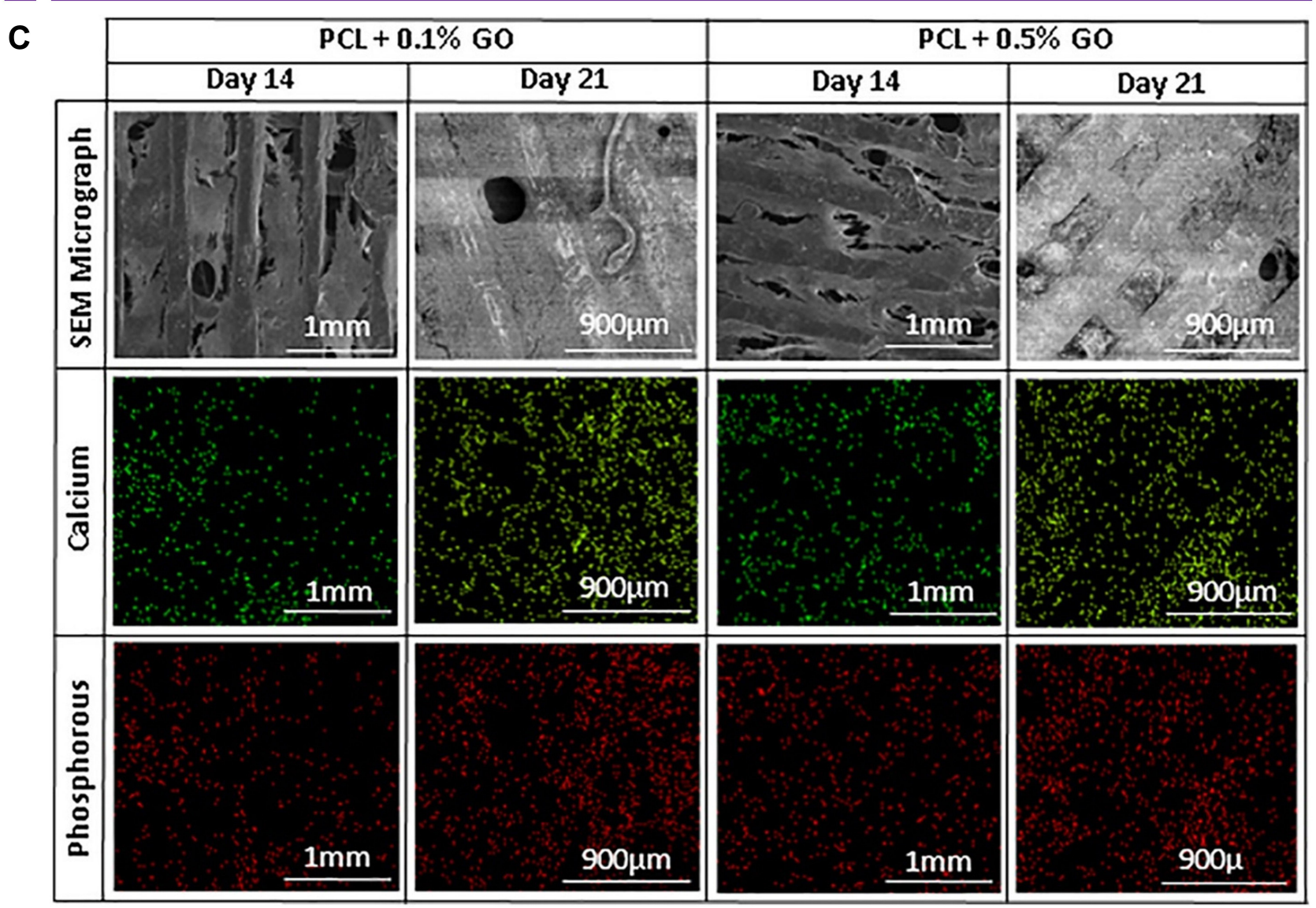

Figure 6 (A) The quantification of ALP activity of murine preosteoblasts attached to PCL-GO scaffolds at days 3,7 , and I4. *Indicated the $p<0.05$, $n=3$. (B) Quantitative analysis of calcium and phosphorus mineralization in PCL-GO scaffolds at days 14 and 21 by EDX method. *Indicated the $p<0.05, n=3$. (C) The calcium and phosphorus profiles and SEM images of the PCL-GO scaffolds were obtained on the 14th and 2 Ist day after osteogenic differentiation. Reprinted from Materials Science and Engineering: $C$, Vol 102, Unagolla JM, Jayasuriya AC, Enhanced cell functions on graphene oxide incorporated 3D printed polycaprolactone scaffolds, Pages No.I-I, Copyright (20I9), with permission from Elsevier. ${ }^{140}$

differentiation of BMSCs by activating MAPK, tumor necrosis factor (TNF) and chemokine signals, thus promoting bone regeneration. In another case, Halim et al $^{146}$ studied the signaling pathways of GO controlling the differentiation of stem cells into osteoblasts. GO was made into suspension with a concentration of $0.1 \mu \mathrm{g} / \mathrm{mL}$ and 
Table 4 Study on the Signaling Pathways Involved in GDs-Induced Osteogenic Differentiation of Stem Cells

\begin{tabular}{|c|c|c|c|c|c|}
\hline $\begin{array}{l}\text { Signaling } \\
\text { Pathways }\end{array}$ & Materials & Structure & Stem Cell Species & Method & References \\
\hline \multirow[t]{3}{*}{$\begin{array}{l}\text { Wnt } / \beta- \\
\text { catenin }\end{array}$} & $\begin{array}{l}\beta \text {-tricalcium } \\
\text { phosphate }(\beta \text {-TCP) } \\
\text { /graphene oxide }(\mathrm{GO})\end{array}$ & $\begin{array}{l}\text { GO: coating } \\
\beta \text {-TCP: 3D } \\
\text { scaffolds }\end{array}$ & BMSCs & $\begin{array}{l}\text { The cells were cultured on GO coating, which was prepared by } \\
\text { immersion in aqueous suspension and heat treatment for I, 3, } 7 \\
\text { and } 14 \text { days. }\end{array}$ & {$[4 I]$} \\
\hline & $\mathrm{GO} / \mathrm{Fe}_{3} \mathrm{O}_{4}$ & Nanoparticles & BMSCs & $\begin{array}{l}\text { The } \mathrm{GO} / \mathrm{Fe}_{3} \mathrm{O}_{4} \text { nanoparticles prepared by chemical } \\
\text { coprecipitation of ferric trichloride and ammonia were added to } \\
\text { the cell suspension, and cultured for } I, 3,5,7,14 \text { and } 21 \text { days. }\end{array}$ & {$[58]$} \\
\hline & $\begin{array}{l}\text { Graphene oxide } \\
\text { quantum dots } \\
\text { (GOQDs) }\end{array}$ & Suspension & $\begin{array}{l}\text { Stem cells from } \\
\text { human exfoliated } \\
\text { deciduous teeth } \\
\text { (SHEDs) }\end{array}$ & $\begin{array}{l}\text { GOQDs was dispersed by ultrasound and cultured in cell } \\
\text { suspension for I, 3, 5, } 7 \text { and I } 4 \text { days. }\end{array}$ & [149] \\
\hline $\begin{array}{l}\mathrm{PI} 3 \mathrm{~K} / \mathrm{Akt} / \\
\mathrm{GSK}-3 \beta / \beta- \\
\text { catenin }\end{array}$ & $\begin{array}{l}\text { GO/poly(lactic-co- } \\
\text { glycolic acid) (PLGA) }\end{array}$ & Films & BMSCs & $\begin{array}{l}\text { The cells were cultured on GO/PLGA films, which were } \\
\text { prepared by acetone solution and mold casting for I, } 3,7 \text { and } \\
14 \text { days. }\end{array}$ & {$[42]$} \\
\hline \multirow{5}{*}{$\begin{array}{l}\text { MAPK and } \\
\text { its } \\
\text { subspecies } \\
(\text { ERKI/2, } \\
\text { P38) }\end{array}$} & $\begin{array}{l}\text { GO/Strontium }(\mathrm{Sr}) / \\
\text { collagen }\end{array}$ & $\begin{array}{l}\text { Porous } \\
\text { scaffolds }\end{array}$ & $\begin{array}{l}\text { Adipose-derived } \\
\text { stem cells (ADSCs) }\end{array}$ & $\begin{array}{l}\text { The cells were cultured on porous scaffolds, which were } \\
\text { crosslinked by EDC/NHS and freeze-drying for I, } 3 \text { and } 14 \text { days. }\end{array}$ & [43] \\
\hline & $\begin{array}{l}\text { GO/sericin } \\
\text { methacryloyl (SerMA) }\end{array}$ & $\begin{array}{l}\text { Porous } \\
\text { hydrogels }\end{array}$ & BMSCs & $\begin{array}{l}\text { The cells were cultured on GO/SERMA porous hydrogels, } \\
\text { which were prepared by UV cross-linking method for I day. }\end{array}$ & {$[144]$} \\
\hline & $\begin{array}{l}\text { GO/copper }(\mathrm{Cu}) / \\
\text { calcium } \\
\text { phosphate }(\mathrm{CaP})\end{array}$ & $\begin{array}{l}\text { GO/Cu: coating } \\
\text { CaP: porous } \\
\text { scaffolds }\end{array}$ & BMSCs & $\begin{array}{l}\text { The cells were cultured on } \mathrm{GO} / \mathrm{Cu} \text { coating, which was } \\
\text { synthesized in situ by } \mathrm{CuSO}_{4} \text { and ascorbic acid for I, 3, } 7 \text { and } \\
14 \text { days. }\end{array}$ & {$[145]$} \\
\hline & $\begin{array}{l}\text { Graphene/CaP/ } \\
\text { chitosan/magnesium } \\
(\mathrm{Mg}) \text { alloy }\end{array}$ & $\begin{array}{l}\text { Graphene } \\
\text { nanosheets/ } \\
\text { CaP/CS: porous } \\
\text { coating }\end{array}$ & BMSCs & $\begin{array}{l}\text { The cells were cultured on graphene/CaP/CS porous coating, } \\
\text { which was prepared by electrophoresis deposition (EPD) for I, } \\
2,8,16 \text { and } 24 \text { days. }\end{array}$ & {$[147]$} \\
\hline & $\begin{array}{l}\text { Graphene/single- } \\
\text { walled carbon } \\
\text { nanotube (G/ } \\
\text { SWCNT) hybrids }\end{array}$ & Nanoparticles & BMSCs & $\begin{array}{l}\text { G/SWCNT hybrids nanoparticles prepared by chemical vapor } \\
\text { deposition processing were added to the cell suspension, and } \\
\text { cultured for I, 3, } 7 \text { and } 14 \text { days. }\end{array}$ & {$[150]$} \\
\hline $\begin{array}{l}\text { JNK and } \\
\text { FoxOI }\end{array}$ & GO & Suspension & BMSCs & $\begin{array}{l}\text { GO was dispersed by ultrasound and cultured in cell suspension } \\
\text { for I, } 2,3,7 \text { and } 14 \text { days. }\end{array}$ & {$[146]$} \\
\hline \multirow[t]{3}{*}{$\begin{array}{l}\text { Focal } \\
\text { adhesion } \\
\text { kinase (FAK) }\end{array}$} & $\begin{array}{l}\text { GO/chitosan/ } \\
\text { nanohydroxyapatite } \\
(\mathrm{nHA})\end{array}$ & $\begin{array}{l}\text { Porous } \\
\text { scaffolds }\end{array}$ & ADSCs & $\begin{array}{l}\text { The cells were cultured on GO/chitosan/nHA porous scaffolds, } \\
\text { which were crosslinked by EDC/NHS and freeze-drying for I, } 3 \text {, } \\
5,7 \text { and I } 4 \text { days. }\end{array}$ & {$[148]$} \\
\hline & $\begin{array}{l}\text { GO/polyethylene } \\
\text { glycol (PEG) }\end{array}$ & $\begin{array}{l}\text { Porous } \\
\text { hydrogel } \\
\text { scaffold }\end{array}$ & $\begin{array}{l}\text { Tonsil-derived } \\
\text { mesenchymal stem } \\
\text { cells (TMSCs) }\end{array}$ & $\begin{array}{l}\text { The cells were cultured on GO/PEG porous hydrogel scaffolds, } \\
\text { which were coupled by APS and freeze drying for I, } 4,7 \text { and I } 4 \\
\text { days. }\end{array}$ & {$[151]$} \\
\hline & $\begin{array}{l}\text { GO/polyethylene } \\
\text { glycol-acrylate } \\
\text { (PEGA) }\end{array}$ & Hydrogels & ADSCs & $\begin{array}{l}\text { The cells were cultured on GO/PEGA hydrogels, which were } \\
\text { prepared by UV cross-linking method for I, } 7,14 \text { and } 21 \text { days. }\end{array}$ & {$[152]$} \\
\hline
\end{tabular}

then co-cultured with BMSCs. The results showed that GO had no effect on the bioactivity of BMSCs, and it slightly promoted the proliferation of BMSCs. Moreover, the osteoinductive effect of GO was realized by activating c-Jun N-terminal kinase (JNK) and Forkhead transcription factor 1 (FoxO1) signaling pathways.
Secondly, the content of GDs in the composites might affect the signaling pathway of stem cell osteogenic differentiation. For example, Wu et $\mathrm{al}^{42}$ incorporated an appropriate amount of graphene into polylactic-glycolic acid copolymer films, and then they discussed the possible effect of $\mathrm{PI} 3 \mathrm{~K} / \mathrm{AKT} / \mathrm{GSK}-3 \beta / \beta$-catenin signal pathway on 
osteogenic differentiation of BMSCs induced by graphene. The results showed that the expression of total Akt and phosphorylated-Akt (p-Akt) was up-regulated with the increase of graphene nano-tablet concentration to $0.5 \mathrm{wt} . \%$. However, when the concentration of graphene nanoplates further increased to $1.0 \mathrm{wt} . \%$, the expression of Akt and p-Akt decreased. The above results suggested that $0.5 \mathrm{wt} \%$ GO-PLGA showed better osteogenic induction than other graphene groups. Therefore, the content of GDs could affect the signaling pathway of stem cell osteogenic differentiation by regulating the expression of related proteins.

Finally, the composites containing GO were prepared into porous structures, which tended to activate the signal pathways of MAPK and its subspecies (extracellular regulated protein kinases $1 / 2$ and p38). For example, Zhang et $\mathrm{al}^{145}$ prepared $\mathrm{GO} / \mathrm{Cu}$ solution by in-situ synthesis of $\mathrm{CuSO}_{4}$ and ascorbic acid, then coated them on the surface of calcium phosphate $(\mathrm{CaP})$ substrate to fabricate $\mathrm{GO} / \mathrm{Cu} / \mathrm{CaP}$ composite scaffolds. Western blot analysis demonstrated that GO up-regulated the expression of Hif-1 $\alpha$ in BMSCs and secreted bone morphogenetic protein- 2 by activating $1 / 2$ (ERK1/2) signal pathway (a subclass of MAPK).

\section{Immunomodulatory Mechanism of GDs-Induced Bone Regeneration}

In the process of bone repair, immune cells were the first cells to contact and react with the implant. These cells produced growth factors by regulating acute inflammation, which promoted the differentiation of mesenchymal stem cells and played an important role in maintaining bone homeostasis and promoting bone repair. The studies had confirmed that inflammatory cytokines such as Interleukin4 (IL-4), IL-10 and IL-13 could promote osteogenesis, while tumor necrosis factor $\alpha$ (TNF- $\alpha)$, IL-6 and IL-1 had the opposite effect. ${ }^{153,154}$ GDs had been shown to stimulate immune cells to produce different responses. ${ }^{155,156}$ In this subsection, we reviewed the immunomodulatory mechanism of GDs-induced bone regeneration, which was normally in two ways.

One was that GDs stimulated macrophages to transform into M1 phenotype and up-regulated the expression of a variety of pro-inflammatory cytokines, thus creating a good immune microenvironment for osteogenesis. Subsequently, the immune microenvironment could stimulate stem cells to differentiate into osteoblasts. For example, Xue et al $^{157}$ studied the effect of GO on the inflammatory response of mouse macrophage line RAW-264.7 cells and found that the expression of proinflammatory cytokines IL-6, IL-1 $\beta$, Interferon $\gamma$ (IFN- $\gamma$ ), Oncostatin M (OSM) and TNF$\alpha$ was up-regulated in RAW 264.7 cells treated with GO. Subsequently, they used the supernatant of GO/RAW 264.7 as the conditioned medium to culture BMSCs, the results of which showed that the expressions of myeloiddifferentiationfactor88 (MYD88), BMP2, vascular endothelial growth factor (VEGF) and OSM of BMSCs were up-regulated in this conditioned medium, indicating that GO stimulation was beneficial to the formation of immune microenvironment of BMSCs osteogenesis. Finally, they researched the immunomodulatory mechanism of $\mathrm{GO}$ in the osteogenesis of BMSCs. The results demonstrated that the immune microenvironment induced by GO stimulated the osteogenic differentiation of BMSCs through OSM and nuclear factor kappa-B (NFאB)-VEGF signaling pathways.

The other was that GDs activated monocytes, which could increase the release of osteogenic factors and induce stem cells to differentiate into osteoblasts. For example, Bordoni et $\mathrm{al}^{44}$ prepared calcium phosphate (CaP)-GO nanoparticles in phosphate solution/GO/cyclohexane/ethanol system by emulsion synthesis, and verified their activating effect on monocytes. They found that the expression of proinflammatory cytokines such as IL-6, TNF- $\alpha$ was upregulated in the cell culture medium, which confirmed that monocytes were activated. Then, the nanoparticles were cocultured with monocytes and BMSCs to compare the effects of the introduction of $\mathrm{CaP}$ and $\mathrm{CaP}-\mathrm{GO}$ on the osteogenic differentiation of BMSCs. The results showed that GO stimulated monocytes to produce higher osteogenic factors (OSM), which further up-regulated the Wnt and BMP signaling pathways of BMSCs, and finally promoted the osteogenic differentiation of the BMSCs.

\section{Application of GDs in Real-Time Detection of Bone Repair Process}

In the field of bone repair, GDs were used not only as the bone repair material, but also as the contrast agent for in vivo imaging. By being functionalized or compounded with other materials, GDs could be applied to real-time detection of bone repair processes to detect the changes in the structure, tumorigenicity, degradation and mineralization of bone repair materials in complex environments in vivo (Figure 7 and Table 5). In this section, we summarized the related principles and advantages of GDs as a contrast agent.

GDs were used as the contrast agent from these three aspects. Firstly, it had a photoelectric effect to convert the 


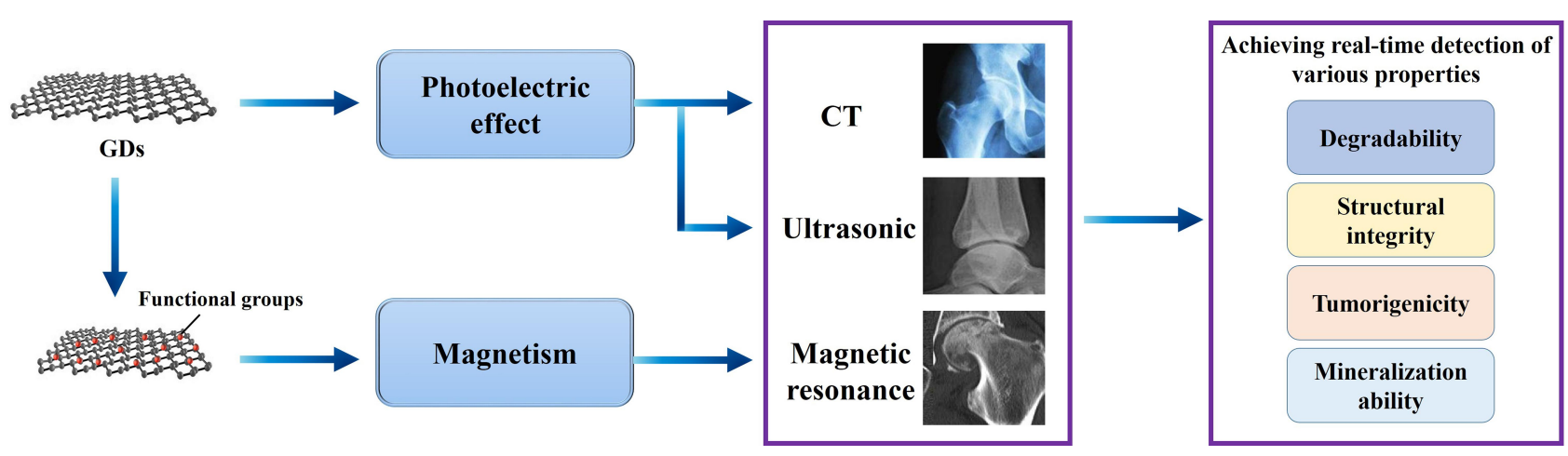

Figure 7 Schematic diagram of real-time detection of GDs as contrast agent. Through the photoelectric effect of GDs themselves and the enhanced magnetism after modification, they can improve the imaging efficiency of composites, thus realizing the real-time detection of various properties.

absorbed electromagnetic energy into sound waves, thus being used in CT and ultrasound. In most cases, GDs were usually prepared in composites for these applications. For example, Kundu et $\mathrm{al}^{48}$ blended $\mathrm{GO}$ with $\mathrm{AgNO}_{3} / \mathrm{NaBH}_{4} /$ human serum albumin (HSA) and $\mathrm{AgNO}_{3} / \mathrm{NaBH}_{4} /$ bovine serum albumin (BSA) system to prepare silver nanocluster (AgNCs)/GO composites as contrast agents and fluorescent markers. The results of CT scanning showed that the introduction of GO enhanced the imaging effect of the composites in Swiss albino mice (Figure 8A and B). Moreover, GO ensured the sustained release of AgNCs in vivo as a stable fluorescent marker and reduced the cytotoxicity of the composite. In another case, Toumia et $\mathrm{al}^{49}$ coated graphene on the surface of polyvinyl alcohol (PVA) microspheres to prepare graphene/PVA (G/ PVA) composites, which were endowed with the function of graphene to convert absorbed radiation into ultrasound waves for contrast agents and based on the nano-microsphere structure, drugs could be loaded for bone repair. The results of in vivo experiments showed that G/PVA as a contrast agent had excellent photoelectric sensitivity and ultrasonic echo ability. In addition, G/PVA could be degraded in vivo and had no cytotoxicity.

Secondly, GDs could obtain magnetism through functionalization to meet the electrophysiological requirements and be used in nuclear magnetic resonance imaging. ${ }^{56,158,159}$ For example, Enayati et al ${ }^{159}$ prepared $\mathrm{rGO}$ by $\gamma$-ray irradiation to study the effects of oxygen functional group content and structural defects on the magnetic properties of rGO. The results showed that under the action of $\gamma$-ray irradiation, the epoxy groups on the surface of $\mathrm{GO}$ were dislodged, resulting in deoxidation defects, so the magnetic properties of rGO were enhanced. Moreover, the degree of oxidation on the surface of GO would also affect its magnetic properties after reduction. The stronger the degree of oxidation, the higher the content of epoxy groups in GO, correspondingly, the higher the defect density of rGO, the stronger the magnetic properties. In another case, Hu's study confirmed that fluorinated graphene oxide (FGO) had magnetic properties due to the existence of C-F bond, so the FGO could be used as a carbon-based contrast agent for magnetic resonance imaging (MRI) without other magnetic nanoparticles. ${ }^{56}$ Moreover, compared with the distribution of proton $\left({ }^{1} \mathrm{H}\right)$ in the human body, the distribution of ${ }^{19} \mathrm{~F}$ was rarer. Therefore, FGO had a higher signal-to-noise ratio compared with the traditional MRI contrast agents.

Thirdly, GDs could be combined with magnetic particles and then introduced into bone repair materials, which could not only make use of the excellent properties of GDs to accelerate bone regeneration, but also enabled that magnetic particles were evenly dispersed and tracked by nuclear magnetic equipment. ${ }^{53,160-162}$ For example, Chen et al ${ }^{53}$ prepared a composite scaffold containing gelatin/PCL/ultra-small paramagnetic iron oxide/GO (Gel/PCL/USPIO/GO) by freeze-drying. The negatively charged GO could effectively combine with the positively charged USPIO, to ensure that the USPIO provided a stable imaging effect for the scaffolds. The results of MRI detection showed that the scaffolds still had clear visual imaging after 7 days of degradation in vitro (Figure 8C). Furthermore, GO could stimulate the proliferation and osteogenic differentiation of BMSCs and provided mechanical support for composite scaffolds. In another case, Pramanik et al $^{162}$ prepared $\mathrm{Fe}_{3} \mathrm{O}_{4} / \mathrm{rGO} /$ poly(hydroxybutyrate-co-valerate) (PHBV) nanocomposite scaffolds. The results showed that the large SSA and lots of surface charges of the rGO enhanced the capture of the graphite lattice by the magnetic particles. Moreover, the rGO could make $\mathrm{Fe}_{3} \mathrm{O}_{4}$ nanoparticles uniformly distributed on its surface, thus realizing the imaging of $\mathrm{Fe}_{3} \mathrm{O}_{4}$ nanoparticles in MRI. Therefore, the degradation process of PHBV-based composites could be 
Table 5 Application of GDs Composites in Real-Time Bone Detection

\begin{tabular}{|c|c|c|c|c|c|}
\hline $\begin{array}{l}\text { Testing } \\
\text { Equipment }\end{array}$ & Composites & $\begin{array}{l}\text { Combination Mode/Modification } \\
\text { Method }\end{array}$ & $\begin{array}{l}\text { The Used } \\
\text { Properties of } \\
\text { Graphene }\end{array}$ & Functions & References \\
\hline \multirow[t]{2}{*}{$\begin{array}{l}\text { Computed } \\
\text { tomography }\end{array}$} & $\mathrm{AgNCs} / \mathrm{GO}$ & AgNCs adsorbed on graphene & Photoelectric effect & $\begin{array}{l}\text { Significant contrast } \\
\text { enhancement of bone } \\
\text { tissues in mice models }\end{array}$ & [48] \\
\hline & $\mathrm{BaGdF}_{5} / \mathrm{GO}$ & $\begin{array}{l}\mathrm{BaGdF}_{5} \mathrm{NPs} \text { were directly grown on the } \\
\text { surface of GO nanosheets by } \\
\text { a solvothermal method }\end{array}$ & Photoelectric effect & $\begin{array}{l}\text { Effective imaging of tumor } \\
\text { model in vivo }\end{array}$ & [52] \\
\hline Ultrasonic & Graphene/PVA & $\begin{array}{l}\text { Graphene was bound to the surface of } \\
\text { PVA microspheres by EDC/NHS. }\end{array}$ & Photoelectric effect & $\begin{array}{l}\text { Performing real-time } \\
\text { multiplex photoacoustic } \\
\text { imaging in vivo }\end{array}$ & [49] \\
\hline \multirow[t]{5}{*}{$\begin{array}{l}\text { Magnetic } \\
\text { resonance } \\
\text { imaging }\end{array}$} & $\begin{array}{l}\text { Ultra-small } \\
\text { paramagnetic } \\
\text { iron oxide } \\
\text { (USPIO)/GO }\end{array}$ & $\begin{array}{l}\text { Covalent binding between amino groups } \\
\text { on USPIO and carboxyl groups on GO }\end{array}$ & $\begin{array}{l}\text { Excellent electrical } \\
\text { conductivity }\end{array}$ & $\begin{array}{l}\text { Real-time detection of } \\
\text { implant degradation }\end{array}$ & [53] \\
\hline & $\begin{array}{l}\text { Fluorinated } \\
\text { graphene } \\
\text { oxide (FGO) }\end{array}$ & $\begin{array}{l}\text { Fluorinated graphite polymer (FG) is } \\
\text { dispersed in a } 9: 1 \text { mixture of concentrated } \\
\text { sulfuric acid and concentrated phosphoric } \\
\text { acid. }\end{array}$ & $\begin{array}{l}\text { Easy to } \\
\text { paramagnetic } \\
\text { modification }\end{array}$ & $\begin{array}{l}\text { It has higher retention time } \\
\text { and imaging efficiency than } \\
\text { the traditional metal } \\
\text { contrast medium. }\end{array}$ & {$[56,158]$} \\
\hline & $\begin{array}{l}\text { Reduced } \\
\text { graphene } \\
\text { oxide (rGO) }\end{array}$ & Reduction of GO by $\gamma$-ray irradiation & $\begin{array}{l}\text { Easy to } \\
\text { paramagnetic } \\
\text { modification }\end{array}$ & Higher imaging efficiency & [159] \\
\hline & $\begin{array}{l}\text { Graphene } \\
\text { quantum dots/ } \\
\text { Gd-DOTA }\end{array}$ & $\begin{array}{l}\text { Graphene quantum dots were crosslinked } \\
\text { with Gd-DOTA by EDC/NHS. }\end{array}$ & $\begin{array}{l}\text { Excellent electrical } \\
\text { conductivity, low } \\
\text { toxicity and high } \\
\text { water solubility }\end{array}$ & $\begin{array}{l}\text { Improving the contrast } \\
\text { enhancement of magnetic } \\
\text { resonance imaging }\end{array}$ & {$[160]$} \\
\hline & $\begin{array}{l}\mathrm{Gd}^{3} \\
+/ \text { Graphene } \\
\text { nanoribbons }\end{array}$ & $\begin{array}{l}\text { The reagent containing } \mathrm{Gd}^{3+} \text { was blended } \\
\text { with graphene, and the mixture was } \\
\text { covalently bound with PCP. }\end{array}$ & $\begin{array}{l}\text { Large specific } \\
\text { surface area }\end{array}$ & $\begin{array}{l}\text { Labeling porcine bone } \\
\text { marrow mesenchymal stem } \\
\text { cells for magnetic } \\
\text { resonance imaging }\end{array}$ & {$[161]$} \\
\hline
\end{tabular}

detected in real time by MRI. In addition, the introduction of rGO enhanced the mechanical strength and electrical conductivity of the composite scaffolds.

\section{Some Concerns About the Application of GDs in Bone Repair}

There were still some concerns about the application of GDs in bone repair materials, including their potential cytotoxicity and possible residues in vivo. In this section, on the one hand, we summarized the mechanism and related factors of GDs-induced cytotoxicity. On the other hand, we reviewed the possible strategies to avoid or decease GDs-induced cytotoxicity, mainly including biological wrapping and biodegradation.

\section{Main Factors of GDs-Induced Cytotoxicity}

The relative studies had shown that GDs might induce cytotoxicity by depleting mitochondrial membrane potential (MMP) and increasing intracellular reactive oxygen species (ROS), thus triggering apoptosis. Moreover, the potential cytotoxicity of GDs was related to their concentration, size, shape, and degree of functionalization.

Firstly, some studies had confirmed that GDs had concentration-dependent cytotoxicity. ${ }^{163,164}$ When the concentration of graphene in the solution was too high, it could cause a high level of oxidative stress by accumulating on the membrane, resulting in physical destruction of cells in the way of membrane penetration, or cell vitality was endangered through the interaction between the 
A

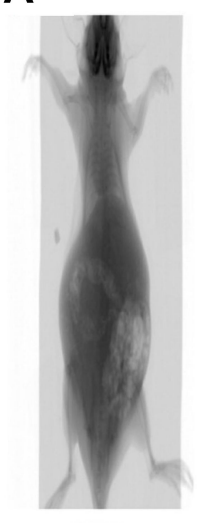

Control

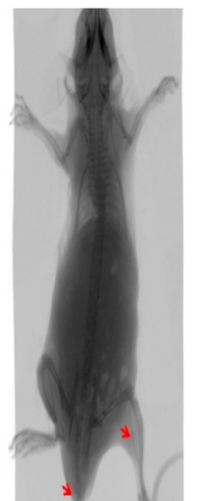

Ag-HSAYCs

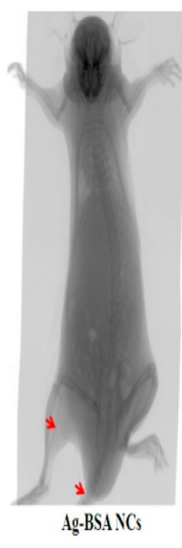

B

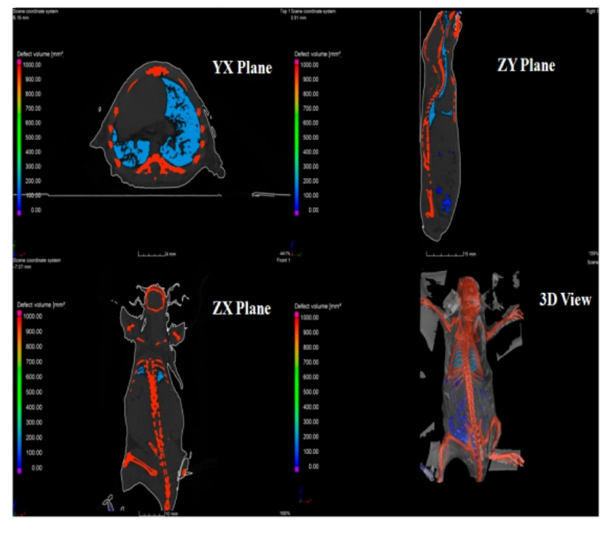

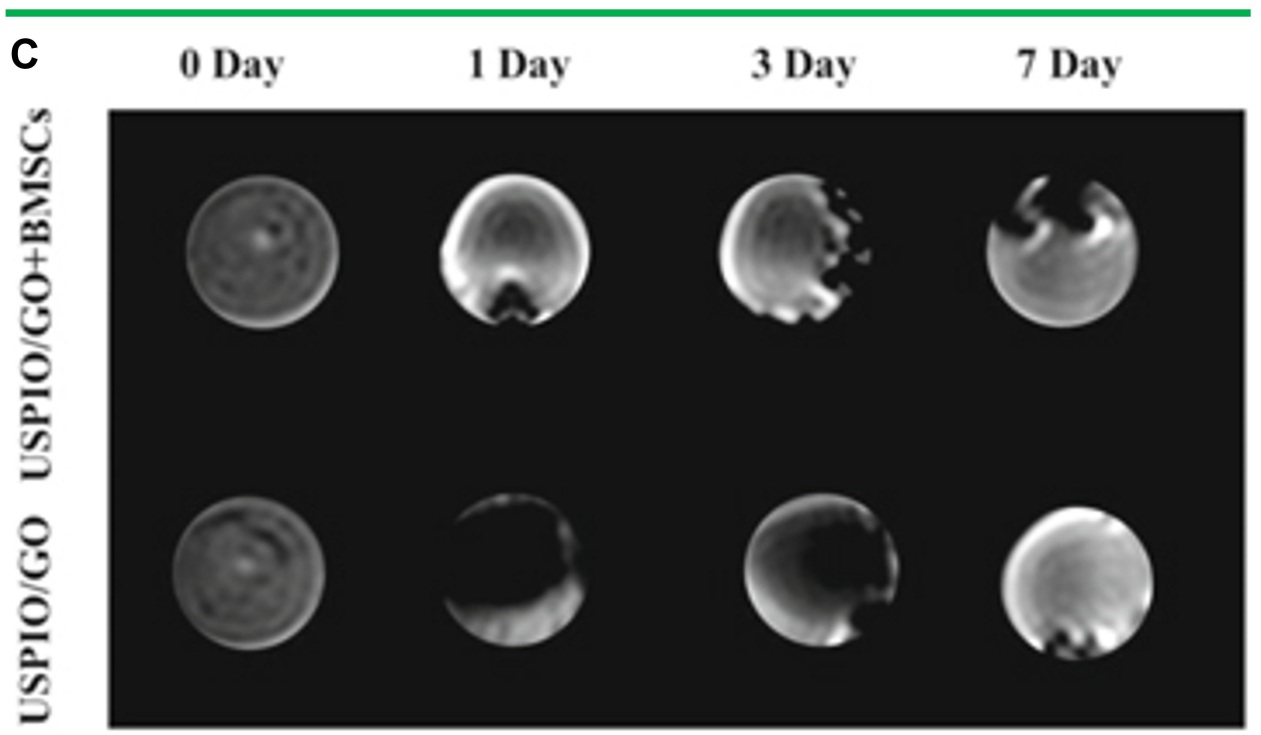

Figure 8 (A) Preprocessing CT images of Swiss albino mice were treated with AgNCs/GO composites. (B) Postprocessing CT images of Swiss albino mice were treated with $\mathrm{AgNCs} / \mathrm{GO}$ composites, including top view, right view, front view and 3D view. (C) magnetic resonance imaging (MRI) contrast of Gel/PCL/USPIO/GO scaffolds with and without BMSCs in vitro. Reproduced with permission of American Chemical Society from Kundu N, Mukherjee D, Maiti TK, Sarkar N. Protein-guided formation of silver nanoclusters and their assembly with graphene oxide as an improved bioimaging agent with reduced toxicity. J Phys Chem Lett. 20I7;8(I0):229I-2297. (A and B). Further permissions related to the material should be directed to the ACS. ${ }^{48}$ Reproduced with permission of IOP Publishing, Ltd from Chen J, Hu HL, Feng LB, et al. Preparation and characterization of 3D porous conductive scaffolds with magnetic resonance enhancement in tissue engineering. Biomed Mater. 2019;14(4):0450I3; permission conveyed through Copyright Clearance Center, Inc (C). ${ }^{53}$

hydrophobic surface of graphene and the cytoplasmic matrix. For example, Pang et $\mathrm{al}^{163}$ found that graphene had little cytotoxicity when the concentration of graphene was in the range of $5 \sim 10 \mu \mathrm{g} / \mathrm{mL}$. In vitro studies had demonstrated that when the concentration of graphene or GO was $10 \mu \mathrm{g} / \mathrm{mL}$, the adhesion and morphology of BMSCs were good. When the concentration of graphene was more than $50 \mu \mathrm{g} / \mathrm{mL}$, the cell size became smaller, its surface secretion increased and the microvilli extended. When the concentration of GO was more than $50 \mu \mathrm{g} / \mathrm{mL}$, BMSCs shrunk and deformed, and most of the cells died. These results also suggested that at the same concentration, the cytotoxic effect of GO on BMSCs was higher than that of graphene. This might be due to the stronger adsorption capacity of GO, which could adsorb serum proteins to form protein inclusion bodies.

Secondly, size had an important effect on the cytotoxicity of GDs. ${ }^{165-167}$ For example, Wychowaniec et al ${ }^{165}$ prepared GO paper using two different sizes of GO sheets (4.9 $\mu \mathrm{m}$ and $151.6 \mathrm{~nm})$. The results of in vitro experiments showed that GO paper prepared with smaller size GO sheets had higher cytotoxicity, which might be due to the different mechanisms of interaction between GO sheets of different sizes and cells. The larger GO sheets first attached to the cell surface, then the membrane invagination and pseudopodia extension, and finally entered the 
cells mainly through phagocytosis, while the smaller GO sheets mainly entered the cells through molecular sievemediated endocytosis. In another case, Gurunathan et al ${ }^{166}$ studied the cytotoxic effects of GO with sizes of $100 \mathrm{~nm}$ and $20 \mathrm{~nm}$ (GO-100 and GO-20) on Leydig (TM3) and Sertoli (TM4) cells. The results showed that the cell viability and cell proliferation induced by GO-20 were significantly lower than those induced by GO-100, the reason of which might be that GO-20 could significantly increase intracellular ROS, induce the significant decreasing of MMP, up-regulate the expression of pro-apoptotic genes, and down-regulate the expression of anti-apoptotic genes. Moreover, they also found that the cytotoxicity of GO-100 and GO-20 might be due to the regulation of EGFR/AKT signal transduction pathway of the TM3 and TM4 cells.

Thirdly, the various shapes of GDs also led to the complexity of their cytotoxicity. ${ }^{168-170}$ For example, Wu et $\mathrm{al}^{168}$ prepared $\mathrm{rGO}$ using $\mathrm{Na}_{2} \mathrm{~S}$ as a reductant and compared the cytotoxicity of GO and rGO with different reduction degrees on primary bone marrow-derived macrophages (BMDMs). The results of in vitro evaluation showed that the cytotoxicity of rGO was higher than that of $\mathrm{GO}$, the main reason of which was found not the change of composition caused by reduction, but the morphology change from the flake of GO to the polygonal crimped shape of rGO. Therefore, rGO with the structure stimulated more ROS production than GO in BMDMs. Moreover, the observation of cell morphology showed that GO enlarged the cell body and prolonged the processes of BMDMs, while rGO caused the size of cells to become smaller and the length of processes shortened, which might be due to the fact that rGO was more likely to condense in the cytoplasm and cause higher cytotoxicity to macrophages. In another case, Dervin et al ${ }^{169}$ prepared two kinds of rGO (H-rGO and AA-rGO) using hydrazine and ascorbic acid as reductants, respectively and compared the cytotoxicity of GO, H-rGO and AA-rGO to A549 human lung epithelial cancer cells. Transmission electron microscope (TEM) observation demonstrated that the shape of H-rGO remained almost unchanged after hydrazine treatment, while the plane structure of AA-rGO was distorted and sharp protuberances appeared on the edge after ascorbic acid treatment. The results of in vitro experiments showed that the cytotoxicity of AA-rGO was higher than that of GO and H-rGO. The reason for these results might be that the irregular shape of AA-rGO reduced the integrity of cell membrane, resulting in the loss of cell structure and stability, and finally led to cell death. The above results indicated that the shape of GDs had an effect on cytotoxicity.

\section{Main Means of Avoiding or Deceasing GDs-Induced Cytotoxicity}

GDs might cause potential harm if they stayed in the human body for a long time. Until now biological wrapping and biodegradation could be used as the main feasible strategies to avoid or decease GDs-induced cytotoxicity.

GDs could be probably wrapped by regenerated bone tissues with the time going on after implantation, resulting in the avoiding or decreasing diffusion of the residues into other tissues or organs. For example, Zhou et al ${ }^{171}$ prepared three-dimensional porous $\mathrm{HA} / \mathrm{rGO}$ scaffolds and implanted them into the $6 \mathrm{~mm}$ critical-size segmental diaphyseal bone defect of rats to repair the defect. The results showed that $\mathrm{rGO}$ was significantly wrapped in regenerated bone tissue at month 6 after the implantation, which was accomplished mainly by the following steps: growing of the new bone into the scaffold, cracking of the substrate under compression, being exposed of GDs that further accelerated bone regeneration, and eventually being wrapped of GDs by the newly regenerated bone. Histological results demonstrated that there was no obvious deposition of rGO and abnormality in the heart, liver, spleen, kidney, lung and pancreas of the animals. The above results might be related to factors such as the pore size, porosity, GDs content, substrate degradability of the scaffolds.

On the other hand, the biodegradation of GDs was mainly through the action of some specific enzymes, such as myeloperoxidase (MPO) and horseradish peroxidase (HRP). These enzymes mainly interacted with hydrogen peroxide $\left(\mathrm{H}_{2} \mathrm{O}_{2}\right)$ produced during metabolism in the body. The $\mathrm{H}_{2} \mathrm{O}_{2}$ was catalyzed by the enzyme to produce strong oxidant hypochloric acid and reaction free radical intermediate, which cleaved the hydroxyl and epoxy groups connected to $\mathrm{C}$ atoms on GDs to form porous amorphous graphene. On the basis of the above principles, the effects of dispersion, layer number, oxygen-containing functional group content and functionalization of GDs on their biodegradation rate were studied. For example, Kurapati et $\mathrm{al}^{62}$ found that the better the dispersion of $\mathrm{GO}$, the easier it was to be degraded by MPO. These effects included electrostatic repulsion between GO layers leading to better dispersion of GO to form stable colloids, and MPO tended to interact with the negative charge on 
the surface of $\mathrm{GO}$, thus inducing $\mathrm{GO}$ degradation at the position of carbon atoms connected to oxygen-containing groups. Subsequently, they also found that monolayer graphene (MLG) and few layer graphene (FLG) could be degraded by MPO in the presence of $\mathrm{H}_{2} \mathrm{O}_{2}$ and $\mathrm{NaCl}$ without chemically functionalized and stable surfactants. ${ }^{63}$ The degradation rate of MLG by MPO was slower compared with that of FLG, which was probably because there were fewer defects and low content of oxygen-containing functional groups on the surface of MLG, so that there were relatively few contact sites between MLG and MPO.

Because the functional groups on the surface of GDs could affect their degradation, the regulation effect of functionalization on the degradation rate of those had been studied. For example, Li et al ${ }^{172}$ prepared functionalized GO by polyethylene glycol (PEG) and bovine serum albumin (BSA). The results of in vitro experiments showed that both peg-modified and BSA-functionalized GO could not be degraded by HRP, which might be due to the steric hindrance provided by PEG and BSA, thus preventing the interaction between HRP and GO surface. Subsequently, they functionalized GO with disulfide bonds to form GO-SS-

PEG and found that GO-SS-PEG could be degraded in mice, which possibly because GO-SS-PEG interacted with macrophages in the body destroyed the disulfide bonds in GO-SS-PEG, thus promoting the contact of the enzyme with GO.

Above all, it is possible for GDs to be biologically wrapped in vivo to decrease their negative effects on other tissues or organs. Moreover, another one of the effective methods to further reduce and avoid the cytotoxicity of GDs could be to introduce GDs evenly into the substrate, which not only avoided the direct contact between GDs and cells to reduce the probability of cell destruction, but also attracted the biological enzymes through the charge on the surface of GDs and substrate, thus accelerating the degradation of GDs.

\section{Summary and Prospect}

It has been proved that GDs, as a bone repair material, have the advantages of excellent mechanical properties, good electrical conductivity, large SSA, easy modification and so on. Among them, the mechanical reinforcement of GDs on bone repair composites is mainly affected by their content. With the increase of GDs content, the mechanical properties of composites have a trend of increasing at first and then decreasing, mainly through agglomeration and changing the mechanical mechanism of pullout effect. Then, the good electrical conductivity of GDs can not only improve the electrical conductivity of bone repair materials directly through the characteristics of low impedance and high charge, but also indirectly enhance those by changing the phase structure of the matrix, thus transmitting electrical signals to improve the bone regeneration behavior of cells and tissues. Subsequently, through the modification of different functional groups, the properties of GDs such as dispersibility and hydrophilicity are significantly improved in the composites, thus enhancing the functions related to bone repair and the binding ability of GDs to active substances.

Moreover, GDs can combine with various matrices in different ways, endowing the matrix with better properties, resulting in further improving the functions of cells such as adhesion, proliferation, osteogenic differentiation and osteoblast-related mineralization. In addition, some studies have reported that the signaling pathways involved in GDs-induced bone regeneration might be affected by the content of GDs, functional groups and the structure of composites. In particular, some possible rules have been found. For example, the porous structure of composites containing GDs is tending to activate the MAPK signal pathway. Furthermore, it has been confirmed that GDs can regulate immunity to induce bone regeneration. After implantation, GDs first interact with immune cells to upregulate the expression of a variety of pro-inflammatory cytokines, thus stimulating stem cells to differentiate into osteoblasts.

On the other hand, GDs can also be used as a contrast agent in the field of bone repair. Using photoelectric effect, composites containing GDs can be used for CT and ultrasonic testing. In another case, the magnetic properties of GDs-containing composites can be changed by functional modification of GDs or compounding with GDs and magnetic particles, which can be used in nuclear magnetic resonance. Finally, we also summarized the factors related to the mechanism of cytotoxicity induced by GDs. It has been confirmed that the cytotoxicity of GDs can be reduced or even avoided by controlling some parameters of GDs, such as the concentration, size and shape of nanosheets. Additionally, most studies have found that biodegradation or biological wrapping could be used as the feasible strategy to solve the residues of GDs. 
Many studies have confirmed that GDs have a broad application prospect in the field of bone repair, but there are still some challenges to be solved before they are used in clinics, including the following aspects.

Firstly, the uniform dispersion of GDs in the matrix has been found to significantly affect the performance of bone repair materials, but the evaluation is only qualitative, lacking common evaluation criteria.

Secondly, for the use of GDs to reinforce bone repair materials, although effects of many parameters such as the number of layers, content and functional modification have been investigated, further studies on the influence of the matrix porosity together with those parameters are necessary because most of the current bone repair materials are porous. On the other hand, a lot of work has been done to improve the combination of the GDs and matrices and enhance the reinforcing effectiveness, including the functionalization of GDs. However, the corresponding systematic research is still lacking, such as that on the effects of different composition means of the GDs and matrices including various kinds of covalent bindings and non-covalent combinations. Moreover, how the treatments affect the mechanical properties of GDs themselves has not been revealed.

Thirdly, it has been proved that the excellent conductivity of GDs can be used to conduct electrical signals, thus promoting the bone regeneration behavior of cells and tissues. At present, the effects of GDs parameters such as content, defect density and modification of the specific functional group on the electrical conductivity of the composites have been investigated. In future, the effect of interface interaction between GDs and matrices on the electrical conductivity of composites should be systematically studied. For example, the effect of GDs binding with different matrices on the electrical conductivity of composites, or the effect of GDs binding and the same matrix on the electrical conductivity of composites. Moreover, the effects of electrical conductivity of GDs composites on osteogenic function and bone tissue regeneration behavior should be studied in vitro and in vivo without external electric field. In addition, the addition of conditions to promote bone repair has become a more recognized method. For example, piezoelectric materials containing GDs have been prepared, which can convert external stimuli into electrical signals, thus promoting bone regeneration through the conductivity of GDs. In future research, it is necessary to develop more functional composites based on GDs, which can convert various external stimuli such as magnetic stimulation and light stimulation into electrical signals, so as to further stimulate the osteogenesis-related functions of cells.

Fourthly, some progress has been made in the mechanism of GDs-induced osteogenesis and immune regulation. In order to achieve controllable regulation of specific signal pathways, it is necessary to further study how the parameters such as the size, shape, microstructure of GDs and the preparation technology of composites with different matrices affect cell-induced osteogenesis and immunomodulatory mechanism.

Fifthly, GDs has been used as a contrast agent in the field of bone repair to achieve real-time detection of the bone repair process, but the effects of GDs parameters such as size, defect density and the method of assembly with the substrate on the imaging effect need to be studied systematically.

Sixthly, in terms of the potential cytotoxicity of GDs, the effects of some parameters such as concentration, size and shape of GDs on cytotoxicity have been investigated to some extent. In future, it is necessary to deeply study the influence of those parameters on the degree and detailed process of damage to cells and related signaling pathways by utilizing some special techniques or methods, such as high-content cell imaging analysis system ${ }^{173}$ and freezing electron microscope. ${ }^{174}$ On the other hand, the used animal models are mainly rats, lacking large animal models such as goats, canines and monkeys. Moreover, due to the limitation of experimental time, there is a lack of chronic toxicity studies for more than 6 months, such as those on the possible effects of GDs on animal reproduction and carcinogenesis.

In addition, the biodegradation of GDs should be deeply explored, such as how the changes in the size, crimp and folding of GDs affect their cytotoxicity or inflammation in the process of enzymatic degradation, as well as the study of different metabolic pathways of GDs, such as urine, sweat and feces. These technical breakthroughs will clear the way for GDs to be used in clinics earlier.

\section{Acknowledgments}

The authors acknowledge financial support from the National Natural Science Foundation of China (No. 31771042), Fok Ying Tung Education Foundation (No. 141039), the Fund of Key Laboratory of Advanced Materials of Ministry of Education (No. 2020AML10), International Joint Research Center of Aerospace Biotechnology and Medical Engineering, Ministry of Science and Technology of China, the 111 Project (No. 
B13003), and the Academic Excellence Foundation of BUAA for PhD Students.

\section{Disclosure}

The authors declare no conflicts of interest for this work.

\section{References}

1. Smith BD, Grande DA. The current state of scaffolds for musculoskeletal regenerative applications. Nat Rev Rheumatol. 2015;11 (4):213-222. doi:10.1038/nrrheum.2015.27

2. Liu M, Zeng $\mathrm{X}, \mathrm{Ma} \mathrm{C}$, et al. Injectable hydrogels for cartilage and bone tissue engineering. Bone Res. 2017;5:17014. doi:10.1038/ boneres.2017.14

3. Lienemann PS, Lutolf MP, Ehrbar M. Biomimetic hydrogels for controlled biomolecule delivery to augment bone regeneration. Adv Drug Deliv Rev. 2012;64(12):1078-1089. doi:10.1016/j. addr.2012.03.010

4. Zhang YB, Yu JK, Ren KX, Zuo JL, Ding JX, Chen XS. Thermosensitive hydrogels as scaffolds for cartilage tissue engineering. Biomacromolecules. 2019;20(4):1478-1492. doi:10.1021/acs.biomac.9b00043

5. Benlidayi ME, Tatli U, Salimov F, Tukel HC, Yuksel O. Comparison of autogenous and allograft bone rings in surgically created vertical bone defects around implants in a sheep model. Clin Oral Implant Res. 2018;29(11):1155-1162. doi:10.1111/clr.13379

6. Oladeji LO, Stannard JP, Cook CR, et al. Effects of autogenous bone marrow aspirate concentrate on radiographic integration of femoral condylar osteochondral allografts. Am J Sports Med. 2017;45(12):2797-2803. doi:10.1177/0363546517715725

7. Wang QF, Yan JH, Yang JL, Li BY. Nanomaterials promise better bone repair. Mater Today. 2016;19(8):451-463. doi:10.1016/j. mattod.2015.12.003

8. Du ZP, Feng XX, Cao GX, et al. The effect of carbon nanotubes on osteogenic functions of adipose-derived mesenchymal stem cells in vitro and bone formation in vivo compared with that of nano-hydroxyapatite and the possible mechanism. Bioact. Mater. 2021;6(2):333-345. doi:10.1016/j.bioactmat.2020.08.015

9. Li G, Zhou T, Lin S, Shi S, Lin Y. Nanomaterials for craniofacial and dental tissue engineering. $J$ Dent Res. 2017;96(7):725-732. doi:10.1177/0022034517706678

10. Eivazzadeh-Keihan R, Maleki A, de la Guardia M, et al. Carbon based nanomaterials for tissue engineering of bone: building new bone on small black scaffolds: a review. $J$ Adv Res. 2019;18:185-201. doi:10.1016/j.jare.2019.03.011

11. Kim S, Ku SH, Lim SY, Kim JH, Park CB. Graphene-biomineral hybrid materials. Adv Mater. 2011;23(17):2009-2014. doi:10.1002/adma.201100010

12. Shin SR, Li YC, Jang HL, et al. Graphene-based materials for tissue engineering. Adv Drug Deliv Rev. 2016;105B:255-274. doi:10.1016/j.addr.2016.03.007

13. Nasiri F, Ajeli S, Semnani D, Jahanshahi M, Emadi R. Design, fabrication and structural optimization of tubular carbon/Kevlar((R))/PMMA/ graphene nanoplate composite for bone fixation prosthesis. Biomed Mater. 2018;13(4):045010. doi:10.1088/1748-605X/aab8d6

14. Turk M, Deliormanli AM. Electrically conductive borate-based bioactive glass scaffolds for bone tissue engineering applications. J Biomater Appl. 2017;32(1):28-39. doi:10.1177/ 0885328217709608

15. Dalgic AD, Alshemary AZ, Tezcaner A, Keskin D, Evis Z. Silicatedoped nano-hydroxyapatite/graphene oxide composite reinforced fibrous scaffolds for bone tissue engineering. J Biomater Appl. 2018;32(10):1392-1405. doi:10.1177/0885328218763665
16. Sharma SS, Sharma BB, Parashar A. Mechanical and fracture behavior of water submerged graphene. J Appl Phys. 2019;125 (21):215107. doi:10.1063/1.5088884

17. Raslan A, Del Burgo LS, Ciriza J, Pedraz JL. Graphene oxide and reduced graphene oxide-based scaffolds in regenerative medicine. Int J Pharm. 2020;580:119226. doi:10.1016/j. ijpharm.2020.119226

18. Li XY, Liu YM, Li WG, et al. Effects of graphene oxide agglomerates on workability, hydration, microstructure and compressive strength of cement paste. Constr Build Mater. 2017;145:402-410. doi:10.1016/j.conbuildmat.2017.04.058

19. Bai RG, Ninan N, Muthoosamy K, Manickam S. Graphene: a versatile platform for nanotheranostics and tissue engineering. Prog Mater Sci. 2018;91:24-69. doi:10.1016/j.pmatsci. 2017.08.004

20. Pattnaik S, Swain K, Lin ZQ. Graphene and graphene-based nanocomposites: biomedical applications and biosafety. $J$ Mat Chem B. 2016;4(48):7813-7831. doi:10.1039/c6tb02086k

21. Paz E, Forriol F, Del Real JC, Dunne N. Graphene oxide versus graphene for optimisation of PMMA bone cement for orthopaedic applications. Mater Sci Eng C-Mater Biol Appl. 2017;77:1003-1011. doi:10.1016/j.msec.2017.03.269

22. Deepachitra R, Chamundeeswari M, Kumar BS, et al. Osteo mineralization of fibrin-decorated graphene oxide. Carbon. 2013;56:64-76. doi:10.1016/j.carbon.2012.12.070

23. Mahmood M, Villagarcia H, Dervishi E, et al. Role of carbonaceous nanomaterials in stimulating osteogenesis in mammalian bone cells. J Mat Chem B. 2013;1(25):3220-3230. doi:10.1039/c3tb20248h

24. Sharma R, Kapusetti G, Bhong SY, et al. Osteoconductive amine functionalized graphene-poly(methylmethacrylate) bone cement composite with controlled exothermic polymerization. Bioconjugate Chem. 2017;28(9):2254-2265. doi:10.1021/acs. bioconjchem. $7 \mathrm{~b} 00241$

25. Sun J, Deng Y, Li JP, et al. A new graphene derivative: hydroxylated graphene with excellent biocompatibility. ACS Appl Mater Interfaces. 2016;8(16):10226-10233. doi:10.1021/acsami.6b02032

26. Eckhart KE, Holt BD, Laurencin MG, Sydlik SA. Covalent conjugation of bioactive peptides to graphene oxide for biomedical applications. Biomater Sci. 2019;7(9):3876-3885. doi:10.1039/ c9bm00867e

27. La WG, Park S, Yoon HH, et al. Delivery of a therapeutic protein for bone regeneration from a substrate coated with graphene oxide. Small. 2013;9(23):4051-4060. doi:10.1002/smll.201300571

28. Zhou HJ, Jiang M, Xin YC, et al. Surface deposition of graphene layer for bioactivity improvement of biomedical 316 stainless steel. Mater Lett. 2017;192:123-127. doi:10.1016/j. matlet.2016.12.043

29. Yu P, Bao RY, Shi XJ, Yang W, Yang MB. Self-assembled high-strength hydroxyapatite/graphene oxide/chitosan composite hydrogel for bone tissue engineering. Carbohydr Polym. 2017;155:507-515. doi:10.1016/j.carbpol.2016.09.001

30. Dinescu S, Ionita M, Ignat SR, Costache M, Hermenean A. Graphene oxide enhances chitosan-based 3D scaffold properties for bone tissue engineering. Int J Mol Sci. 2019;20(20):5077. doi:10.3390/ijms20205077

31. Zhang YC, Hu JL. Isocyanate modified GO shape-memory polyurethane composite. Polymers. 2020;12(1):118. doi:10.3390/ polym12010118

32. Qi YY, Tai ZX, Sun DF, et al. Fabrication and characterization of poly(vinyl alcohol)/graphene oxide nanofibrous biocomposite scaffolds. J Appl Polym Sci. 2013;127(3):1885-1894. doi:10.1002/app.37924

33. Li DJ, Nie W, Chen L, et al. Self-assembled hydroxyapatite-graphene scaffold for photothermal cancer therapy and bone regeneration. J Biomed Nanotechnol. 2018;14 (12):2003-2017. doi:10.1166/jbn.2018.2646 
34. Li KW, Wang CH, Yan JH, et al. Evaluation of the osteogenesis and osseointegration of titanium alloys coated with graphene: an in vivo study. Sci Rep. 2018;8:1843. doi:10.1038/s41598-018-19742-y

35. Park KO, Lee JH, Park JH, et al. Graphene oxide-coated guided bone regeneration membranes with enhanced osteogenesis: spectroscopic analysis and animal study. Appl Spectrosc Rev. 2016;51 (7-9):540-551. doi:10.1080/05704928.2016.1165687

36. Saravanan S, Vimalraj S, Anuradha D. Chitosan based thermoresponsive hydrogel containing graphene oxide for bone tissue repair. Biomed Pharmacother. 2018;107:908-917. doi:10.1016/j. biopha.2018.08.072

37. Zhai LS, Li L, Zhang Q. Fabrication of capsaicin functionalized reduced graphene oxide and its effect on proliferation and differentiation of osteoblasts. Environ Toxicol Pharmacol. 2018;57:41-45. doi:10.1016/j.etap.2017.11.012

38. Cicuendez M, Silva VS, Hortiguela MJ, Matesanz MC, Vila M, Portoles MT. MC3T3-E1 pre-osteoblast response and differentiation after graphene oxide nanosheet uptake. Colloid Surf B-Bio Interfaces. 2017;158:33-40. doi:10.1016/j.colsurfb.2017.06.019

39. Nayak TR, Andersen H, Makam VS, et al. Graphene for controlled and accelerated osteogenic differentiation of human mesenchymal stem cells. ACS Nano. 2011;5(6):4670-4678. doi:10.1021/nn200500h

40. Arnold AM, Holt BD, Daneshmandi L, Laurencin CT, Sydlik SA. Phosphate graphene as an intrinsically osteoinductive scaffold for stem cell-driven bone regeneration. Proc Natl Acad Sci U S A. 2019;116(11):4855-4860. doi:10.1073/pnas.1815434116

41. Wu CT, Xia LG, Han PP, et al. Graphene-oxide-modified beta-tricalcium phosphate bioceramics stimulate in vitro and in vivo osteogenesis. Carbon. 2015;93:116-129. doi:10.1016/j.carbon.2015.04.048

42. Wu XW, Zheng S, Ye YZ, Wu YC, Lin KL, Su JS. Enhanced osteogenic differentiation and bone regeneration of poly(lactic-co-glycolic acid) by graphene via activation of PI3K/Akt/ GSK-3 beta-beta-catenin signal circuit. Biomater Sci. 2018;6 (5):1147-1158. doi:10.1039/c8bm00127h

43. Chen YH, Zheng ZW, Zhou RP, et al. Developing a strontium-releasing graphene oxide-/collagen-based organic-inorganic nanobiocomposite for large bone defect regeneration via MAPK signaling pathway. ACS Appl Mater Interfaces. 2019;11(17):15986-15997. doi:10.1021/acsami.8b22606

44. Bordoni V, Reina G, Orecchioni M, et al. Stimulation of bone formation by monocyte-activator functionalized graphene oxide in vivo. Nanoscale. 2019;11(41):19408-19421. doi:10.1039/c9nr03975a

45. Chang TK, Lu YC, Yeh ST, Lin TC, Huang CH, Huang CH. In vitro and in vivo biological responses to graphene and graphene oxide: a murine calvarial animal study. Int $J$ Nanomed. 2020;15:647-659. doi:10.2147/IJN.S231885

46. Yao QQ, Liu HX, Lin X, et al. 3D interpenetrated graphene foam/ $58 \mathrm{~S}$ bioactive glass scaffolds for electrical-stimulation-assisted differentiation of rabbit mesenchymal stem cells to enhance bone regeneration. J Biomed Nanotechnol. 2019;15(3):602-611. doi:10.1166/jbn.2019.2703

47. Zhang SY, Yang QM, Zhao WK, et al. In vitro and in vivo biocompatibility and osteogenesis of graphene-reinforced nanohydroxyapatite polyamide66 ternary biocomposite as orthopedic implant material. Int $J$ Nanomed. 2016;11:3179-3189. doi:10.2147/IJN.S105794

48. Kundu N, Mukherjee D, Maiti TK, Sarkar N. Protein-guided formation of silver nanoclusters and their assembly with graphene oxide as an improved bioimaging agent with reduced toxicity. $J$ Phys Chem Lett. 2017;8(10):2291-2297. doi:10.1021/acs. jpclett.7b00600

49. Toumia Y, Cerroni B, Trochet P, et al. Performances of a pristine graphene-microbubble hybrid construct as dual imaging contrast agent and assessment of its biodistribution by photoacoustic imaging. Part Part Syst Char. 2018;35(7):1800066. doi:10.1002/ ppsc. 201800066
50. Goncalves G, Cruz SMA, Ramalho A, Gracio J, Marques PAAP. Graphene oxide versus functionalized carbon nanotubes as a reinforcing agent in a PMMA/HA bone cement. Nanoscale. 2012;4(9):2937-2945. doi:10.1039/c2nr30303e

51. Jeon J, Lodge MS, Dawson BD, Ishigami M, Shewmaker F, Chen B. Superb resolution and contrast of transmission electron microscopy images of unstained biological samples on graphene-coated grids. Biochim Biophys Acta-Gen Subj. 2013;1830(6):3807-3815. doi:10.1016/j.bbagen.2013.03.002

52. Zhang $\mathrm{H}$, Wu HX, Wang J, et al. Graphene oxide-BaGdF5 nanocomposites for multi-modal imaging and photothermal therapy. Biomaterials. 2015;42:66-77. doi:10.1016/j. biomaterials.2014.11.055

53. Chen J, Hu HL, Feng LB, et al. Preparation and characterization of $3 \mathrm{D}$ porous conductive scaffolds with magnetic resonance enhancement in tissue engineering. Biomed Mater. 2019;14 (4):045013. doi:10.1088/1748-605X/ab1d9c

54. Talukdar Y, Rashkow JT, Patel S, et al. Nanofilm generated non-pharmacological anabolic bone stimulus. J Biomed Mater Res Part A. 2020;108(1):178-186. doi:10.1002/jbm.a.36807

55. Zapata MEV, Hernandez JHM, Grande Tovar CD, et al. Novel bioactive and antibacterial acrylic bone cement nanocomposites modified with graphene oxide and chitosan. Int $J \mathrm{Mol} \mathrm{Sci}$. 2019;20(12):2938. doi:10.3390/ijms20122938

56. $\mathrm{Hu} \mathrm{YH.} \mathrm{The} \mathrm{first} \mathrm{magnetic-nanoparticle-free} \mathrm{carbon-based} \mathrm{con-}$ trast agent of magnetic-resonance imaging-fluorinated graphene oxide. Small. 2014;10(8):1451-1452. doi:10.1002/smll.20 1303644

57. Chowdhury SM, Dasgupta S, Mcelroy AE, Sitharaman B. Structural disruption increases toxicity of graphene nanoribbons. J Appl Toxicol. 2014;34(11):1235-1246. doi:10.1002/jat.3066

58. He Y, Li YM, Chen GH, et al. Concentration-dependent cellular behavior and osteogenic differentiation effect induced in bone marrow mesenchymal stem cells treated with magnetic graphene oxide. J Biomed Mater Res Part A. 2020;108(1):50-60. doi:10.1002/jbm.a.36791

59. Das S, Singh S, Singh V, et al. Oxygenated functional group density on graphene oxide: its effect on cell toxicity. Part Part Syst Char. 2013;30(2):148-157. doi:10.1002/ppsc.201200066

60. Diez-Pascual AM. Tissue engineering bionanocomposites based on poly(propylene fumarate). Polymers. 2017;9(7):260. doi:10.3390/polym9070260

61. Díez-Pascual AM, Diez-Vicente AL. Poly(propylene fumarate)/ polyethylene glycol-modified graphene oxide nanocomposites for tissue engineering. ACS Appl Mater Interfaces. 2016;8 (28):17902-17914. doi:10.1021/acsami.6b05635

62. Kurapati R, Russier J, Squillaci MA, et al. Dispersibility-dependent biodegradation of graphene oxide by myeloperoxidase. Small. 2015;11 (32):3985-3994. doi:10.1002/smll.201500038

63. Kurapati R, Mukherjee SP, Martin C, et al. Degradation of singlelayer and few-layer graphene by neutrophil myeloperoxidase. Angew Chem-Int Edit. 2018;57(36):11722-11727. doi:10.1002/ anie. 201806906

64. Arnold AM, Holt BD, Tang CX, Sydlik SA. Phosphate modified graphene oxide: long-term biodegradation and cytocompatibility. Carbon. 2019;154:342-349. doi:10.1016/j.carbon.2019.08.005

65. Mohammadi S, Shafiei SS, Asadi-Eydivand M, Ardeshir M, Solati-Hashjin M. Graphene oxide-enriched poly ( $\varepsilon$ caprolactone) electrospun nanocomposite scaffold for bone tissue engineering applications. J Bioact Compat Polym. 2017;32 (3):325-342. doi:10.1177/0883911516668666

66. Wang L, Wang CY, Wu S, Fan YB, Li XM. Influence of mechanical properties of biomaterials on degradability, cell behaviors and signaling pathways: current progress and challenges. Biomater Sci. 2020;8(10):2714-2733. doi:10.1039/d0bm00269k 
67. Wang L, Wu S, Cao GX, Fan YB, Dunne N, Li XM. Biomechanical studies on biomaterial degradation and co-cultured cells: mechanisms, potential applications, challenges and prospects. J Mat Chem B. 2019;7:7439-7459. doi:10.1039/ c9tb01539f

68. Agarwal R, Garcia AJ. Biomaterial strategies for engineering implants for enhanced osseointegration and bone repair. $A d v$ Drug Deliv Rev. 2015;94:53-62. doi:10.1016/j.addr.2015.03.013

69. Yi H, Rehman FU, Zhao CQ, Liu B, He NY. Recent advances in nano scaffolds for bone repair. Bone Res. 2016;4:16050. doi:10.1038/boneres.2016.50

70. Zhu YW, Murali S, Cai WW, et al. Graphene and graphene oxide: synthesis, properties, and applications. Adv Mater. 2010;22 (35):3906-3924. doi:10.1002/adma.201001068

71. Papageorgiou DG, Kinloch IA, Young RJ. Mechanical properties of graphene and graphene-based nanocomposites. Prog Mater Sci. 2017;90:75-127. doi:10.1016/j.pmatsci.2017.07.004

72. Lee C, Wei XD, Kysar JW, Hone J. Measurement of the elastic properties and intrinsic strength of monolayer graphene. Science. 2008;321(5887):385-388. doi:10.1126/science.1157996

73. Young RJ, Kinloch IA, Gong L, Novoselov KS. The mechanics of graphene nanocomposites: a review. Compos Sci Technol. 2012;72(12):1459-1476. doi:10.1016/j.compscitech.2012.05.005

74. Guo SJ, Dong SJ. Graphene nanosheet: synthesis, molecular engineering, thin film, hybrids, and energy and analytical applications. Chem Soc Rev. 2011;40(5):2644-2672. doi:10.1039/c0cs00079e

75. Eqra R, Janghorban K, Manesh HD. Effect of number of graphene layers on mechanical and dielectric properties of graphene-epoxy nanocomposites. Plast Rubber Compos. 2015;44(10):405-412. doi:10.1179/1743289815Y.0000000037

76. Zhang YY, Gu YT. Mechanical properties of graphene: effects of layer number, temperature and isotope. Comput Mater Sci. 2013;71:197-200. doi:10.1016/j.commatsci.2013.01.032

77. Kim HJ, Seo KJ, Kim DE. Investigation of mechanical behavior of single- and multi-layer graphene by using molecular dynamics simulation. Int J Precis Eng Man. 2016;17(12):1693-1701. doi:10.1007/s12541-016-0196-4

78. Tang YF, Chen L, Duan ZH, Zhao K, Wu ZX. Graphene/barium titanate/polymethyl methacrylate bio-piezoelectric composites for biomedical application. Ceram Int. 2020;46(5):6567-6574. doi:10.1016/j.ceramint.2019.11.142

79. Gao DZ, Jing J, Yu JC, et al. Graphene platelets enhanced pressureless-sintered $\mathrm{B}_{4} \mathrm{C}$ ceramics. R Soc Open Sci. 2018;5 (4):171837. doi:10.1098/rsos.171837

80. Yang Y, Ding XL, Zou TQ, Peng G, Liu HF, Fan YB. Preparation and characterization of electrospun graphene/silk fibroin conductive fibrous scaffolds. RSC Adv. 2017;7(13):7954-7963. doi:10.1039/C6RA26807B

81. Ionita M, Crica LE, Tiainen H, et al. Gelatin-poly(vinyl alcohol) porous biocomposites reinforced with graphene oxide as biomaterials. J Mat Chem B. 2015;4(2):282-291. doi:10.1039/ C5TB02132D

82. Zhang HP, Yang B, Wang ZM, et al. Porous graphene oxide/ chitosan nanocomposites based on interfacial chemical interactions. Eur Polym J. 2019;119:114-119. doi:10.1016/j. eurpolymj.2019.07.032

83. Zhang SW, Zhang DD, Li Z, et al. Polydopamine functional reduced graphene oxide for enhanced mechanical and electrical properties of waterborne polyurethane nanocomposites. J Coat Technol Res. 2018;15(6):1333-1341. doi:10.1007/s11998-018-0082-3

84. Liu XF, Miller AL, Waletzki BE, Lu LC. Cross-linkable graphene oxide embedded nanocomposite hydrogel with enhanced mechanics and cytocompatibility for tissue engineering. $J$ Biomed Mater Res Part A. 2018;106(5):1247-1257. doi:10.1002/jbm.a.36322
85. Huang Y, Deng HK, Fan YB, et al. Conductive nanostructured Si biomaterials enhance osteogeneration through electrical stimulation. Mater Sci Eng C-Mater Biol Appl. 2019;103:109748. doi:10.1016/j.msec.2019.109748

86. Pelto J, Bjorninen M, Palli A, et al. Novel polypyrrole-coated polylactide scaffolds enhance adipose stem cell proliferation and early osteogenic differentiation. Tissue Eng Part A. 2013;19(7-8):882-892. doi:10.1089/ten.tea.2012.0111

87. Thrivikraman G, Lee PS, Hess R, Haenchen V, Basu B, Schamweber D. Interplay of substrate conductivity, cellular microenvironment, and pulsatile electrical stimulation toward osteogenesis of human mesenchymal stem cells in vitro. ACS Appl Mater Interfaces. 2015;7(41):23015-23028. doi:10.1021/acsami.5b06390

88. Bonaccorso F, Colombo L, Yu GH, et al. Graphene, related two-dimensional crystals, and hybrid systems for energy conversion and storage. Science. 2015;347(6217):1246501. doi:10.1126/ science. 1246501

89. Zhao GK, Li XM, Huang MR, et al. The physics and chemistry of graphene-on-surfaces. Chem Soc Rev. 2017;46(15):4417-4449. doi:10.1039/C7CS00256D

90. Thompson BC, Murray E, Wallace GG. Graphite oxide to graphene. Biomaterials to bionics. Adv Mater. 2015;27 (46):7563-7582. doi:10.1002/adma.201500411

91. Gong SS, Ni H, Jiang L, Cheng QF. Learning from nature: constructing high performance graphene-based nanocomposites. Mater Today. 2016;20(4):210-219. doi:10.1016/j.mattod.2016.11.002

92. Li JF, Liu X, Crook JM, Wallace GG. Electrical stimulation-induced osteogenesis of human adipose derived stem cells using a conductive graphene-cellulose scaffold. Mater Sci Eng C-Mater Biol Appl. 2020;107:110312. doi:10.1016/j.msec.2019.110312

93. Goodman PA, Li H, Gao Y, Lu YF, Stenger-Smith JD, Redepenning J. Preparation and characterization of high surface area, high porosity carbon monoliths from pyrolyzed bovine bone and their performance as supercapacitor electrodes. Carbon. 2013;55:291-298. doi:10.1016/j.carbon.2012.12.066

94. Jin L, Wu DC, Kuddannaya S, Zhang YL, Wang ZL. Fabrication, characterization, and biocompatibility of polymer cored reduced graphene oxide nanofibers. ACS Appl Mater Interfaces. 2016;8 (8):5170-5177. doi:10.1021/acsami.6b00243

95. Silva M, Caridade SG, Vale AC, et al. Biomedical films of graphene nanoribbons and nanoflakes with natural polymers. RSC Adv. 2017;7(44):27578-27594. doi:10.1039/C7RA04173J

96. Shuai CJ, Zeng ZC, Yang YW, et al. Graphene oxide assists polyvinylidene fluoride scaffold to reconstruct electrical microenvironment of bone tissue. Mater Des. 2020;190:108564. doi:10.1016/j.matdes.2020.108564

97. Azadian E, Arjmand B, Ardeshirylajimi A, Hosseinzadeh S, Omidi M, Khojasteh A. Polyvinyl alcohol modified polyvinylidene fluoride-graphene oxide scaffold promotes osteogenic differentiation potential of human induced pluripotent stem cells. $J$ Cell Biochem. 2019;121(5-6):3185-3196. doi:10.1002/ jcb. 29585

98. Tahriri M, Monico MD, Moghanian A, et al. Graphene and its derivatives: opportunities and challenges in dentistry. Mater Sci Eng C-Mater Biol Appl. 2019;102:171-185. doi:10.1016/j. msec.2019.04.051

99. Mohammadrezaei D, Golzar H, Rad M, et al. In vitro effect of graphene structures as an osteoinductive factor in bone tissue engineering: a systematic review. J Biomed Mater Res Part A. 2018;106(8):2284-2343. doi:10.1002/jbm.a.36422

100. Holt BD, Arnold AM, Sydlik SA. Peptide-functionalized reduced graphene oxide as a bioactive mechanically robust tissue regeneration scaffold. Polym Int. 2017;66(8):1190-1198. doi:10.1002/pi.5375

101. Lee WC, Lim CH, Shi H, et al. Origin of enhanced stem cell growth and differentiation on graphene and graphene oxide. ACS Nano. 2011;5(9):7334-7341. doi:10.1021/nn202190c 
102. Xie CM, Sun HL, Wang KF, Zheng W, Lu X, Ren FZ. Graphene oxide nanolayers as nanoparticle anchors on biomaterial surfaces with nanostructures and charge balance for bone regeneration. $J$ Biomed Mater Res Part A. 2017;105(5):1311-1323. doi:10.1002/jbm.a.36010

103. Chen JY, Zhang X, Cai H, et al. Osteogenic activity and antibacterial effect of zinc oxide/carboxylated graphene oxide nanocomposites: preparation and in vitro evaluation. Colloid Surf B-Bio Interfaces. 2016;147:397-407. doi:10.1016/j. colsurfb.2016.08.023

104. Kaur T, Thirugnanam A, Pramanik K. Effect of carboxylated graphene nanoplatelets on mechanical and in-vitro biological properties of polyvinyl alcohol nanocomposite scaffolds for bone tissue engineering. Mater Today Commun. 2017;12:34-42. doi:10.1016/j.mtcomm.2017.06.004

105. Tavafoghi M, Brodusch N, Gauvin R, Cerruti M. Hydroxyapatite formation on graphene oxide modified with amino acids: arginine versus glutamic acid. $J R$ Soc Interface. 2016;13(114):20150986. doi:10.1016/j.mtcomm.2017.06.004

106. Paz E, Ballesteros Y, Forriol F, Dunne NJ, Del Real JC. Graphene and graphene oxide functionalisation with silanes for advanced dispersion and reinforcement of PMMA-based bone cements. Mater Sci Eng C-Mater Biol Appl. 2019;104:109946. doi:10.1016/j.msec.2019.109946

107. Vuppaladadium SSR, Agarwal T, Kulanthaivel S, et al. Silanization improves biocompatibility of graphene oxide. Mater Sci Eng C-Mater Biol Appl. 2020;110:110647. doi:10.1016/j. msec.2020.110647

108. Jia ZJ, Shi YY, Xiong P, et al. From solution to biointerface: graphene self-assemblies of varying lateral sizes and surface properties for biofilm control and osteodifferentiation. ACS Appl Mater Interfaces. 2016;8(27):17151-17165. doi:10.1021/acsami.6b05198

109. Cheng J, Liu HY, Zhao BJ, et al. MC3T3-E1 preosteoblast cell-mediated mineralization of hydroxyapatite by poly-dopamine-functionalized graphene oxide. J Bioact Compat Polym. 2015;30(3):289-301. doi:10.1177/0883911515569918

110. Padmavathy N, Jaidev LR, Bose S, Chatterjee K. Oligomergrafted graphene in a soft nanocomposite augments mechanical properties and biological activity. Mater Des. 2017;126:238-249. doi:10.1016/j.matdes.2017.03.087

111. Liu XH, Ma DM, Tang H, et al. Polyamidoamine dendrimer and oleic acid-functionalized graphene as biocompatible and efficient gene delivery vectors. ACS Appl Mater Interfaces. 2014;6 (11):8173-8183. doi:10.1021/am500812h

112. Dou C, Ding N, Luo F, et al. Graphene-based microRNA transfection blocks preosteoclast fusion to increase bone formation and vascularization. Adv Sci. 2018;5(2):1700578. doi:10.1002/ advs. 201700578

113. Li KH, Zhang ZF, Li DP, et al. Biomimetic ultralight, highly porous, shape-adjustable, and biocompatible 3D graphene minerals via incorporation of self-assembled peptide nanosheets. $A d v$ Funct Mater. 2018;28(29):1801056. doi:10.1002/ adfm. 201801056

114. Kang ES, Kim DS, Han Y, et al. Three-dimensional graphene-RGD peptide nanoisland composites that enhance the osteogenesis of human adipose-derived mesenchymal stem cells. Int J Mol Sci. 2018;19(3):669. doi:10.3390/ijms19030669

115. Zhang WJ, Yang GZ, Wang XS, et al. Magnetically controlled growth-factor-immobilized multilayer cell sheets for complex tissue regeneration. Adv Mater. 2017;29(43):1703795. doi:10.1002/adma.201703795

116. Yao QQ, Liu YX, Sun HL. Heparin-dopamine functionalized graphene foam for sustained release of bone morphogenetic protein-2. J Tissue Eng Regen Med. 2018;12(6):1519-1529. doi:10.1002/term.2681
117. Unnithan AR, Sasikala ARK, Park CH, Kim CS. A unique scaffold for bone tissue engineering: an osteogenic combination of graphene oxide-hyaluronic acid.chitosan with simvastatin. $J$ Ind Eng Chem. 2017;46:182-191. doi:10.1016/j.jiec.2016.10.029

118. Sun HH, Zhang LF, Xia W, Chen LX, Xu ZZ, Zhang WQ. Fabrication of graphene oxide-modified chitosan for controlled release of dexamethasone phosphate. Appl Phys A-Mater Sci Process. 2016;122(7):632. doi:10.1007/s00339-016-0029-4

119. Weng WZ, Nie W, Zhou QR, et al. Controlled release of vancomycin from 3D porous graphene-based composites for dual-purpose treatment of infected bone defects. RSC $A d v$. 2017;7(5):2753-2765. doi:10.1039/C6RA26062D

120. Liang CY, Luo YC, Yang GD, et al. Graphene oxide hybridized nHAC/PLGA scaffolds facilitate the proliferation of MC3T3-E1 cells. Nanoscale Res Lett. 2018;13:15. doi:10.1186/s11671-0182432-6

121. Li XJ, Lin KL, Wang ZL. Enhanced growth and osteogenic differentiation of MC3T3-E1 cells on Ti6Al4V alloys modified with reduced graphene oxide. RSC Adv. 2017;7 (24):14430-14437. doi:10.1039/c6ra25832h

122. Fu C, Bai HT, Hu Q, Gao TL, Bai YS. Enhanced proliferation and osteogenic differentiation of MC3T3-E1 pre-osteoblasts on graphene oxide-impregnated PLGA-gelatin nanocomposite fibrous membranes. RSC Adv. 2017;7(15):8886-8897. doi:10.1039/c6ra26020a

123. Newby SD, Masi T, Griffin CD, et al. Functionalized graphene nanoparticles induce human mesenchymal stem cells to express distinct extracellular matrix proteins mediating osteogenesis. Int J Nanomed. 2020;15:2501-2513. doi:10.2147/IJN.S245801

124. Krukiewicz K, Putzer D, Stuendl N, Lohberger B, Awaja F. Enhanced osteogenic differentiation of human primary mesenchymal stem and progenitor cultures on graphene oxide/poly(methyl methacrylate) composite scaffolds. Materials. 2020;13(13):2991. doi:10.3390/ma13132991

125. Rostami F, Tamjid E, Behmanesh M. Drug-eluting PCL/graphene oxide nanocomposite scaffolds for enhanced osteogenic differentiation of mesenchymal stem cells. Mater Sci Eng C-Mater Biol Appl. 2020;115:111102. doi:10.1016/j.msec.2020.111102

126. Zou YL, Qazvini NT, Zane KL, et al. Gelatin-derived graphene-silicate hybrid materials are biocompatible and synergistically promote BMP9-induced osteogenic differentiation of mesenchymal stem cells. ACS Appl Mater Interfaces. 2017;9 (19):15922-15932. doi:10.1021/acsami.7b00272

127. Nie W, Peng C, Zhou X, et al. Three-dimensional porous scaffold by self-assembly of reduced graphene oxide and nano-hydroxyapatite composites for bone tissue engineering. Carbon. 2017;116:325-337. doi:10.1016/j.carbon.2017.02.013

128. Yan JH, Wang CH, Li KW, et al. Enhancement of surface bioactivity on carbon fiber-reinforced polyether ether ketone via graphene modification. Int $J$ Nanomed. 2018;13:3425-3440. doi:10.2147/IJN.S160030

129. Hermenean A, Codreanu A, Herman H, et al. Chitosan-graphene oxide $3 \mathrm{D}$ scaffolds as promising tools for bone regeneration in critical-size mouse calvarial defects. Sci Rep. 2017;7:16641. doi:10.1038/s41598-017-16599-5

130. Qiu JJ, Guo JS, Geng H, Qian WH, Liu XY. Three-dimensional porous graphene nanosheets synthesized on the titanium surface for osteogenic differentiation of rat bone mesenchymal stem cells. Carbon. 2017;125:227-235. doi:10.1016/j.carbon.2017.09.064

131. Lyu H, He ZC, Chan YK, He XH, Yu Y, Deng Y. Hierarchical ZnO nanotube/graphene oxide nanostructures endow pure $\mathrm{Zn}$ implant with synergistic bactericidal activity and osteogenicity. Ind Eng Chem Res. 2019;58(42):19377-19385. doi:10.1021/acs.iecr.9b02986

132. Shahin M, Munir K, Wen CE, Li YC. Magnesium-based composites reinforced with graphene nanoplatelets as biodegradable implant materials. $J$ Alloys Compd. 2020;828:154461. doi:10.1016/j.jallcom.2020.154461 
133. Zhao Y, Chen JD, Zou L, Xu G, Geng YS. Facile one-step bioinspired mineralization by chitosan functionalized with graphene oxide to activate bone endogenous regeneration. Chem Eng J. 2019;378:122174. doi:10.1016/j.cej.2019.122174

134. Oguz OD, Ege D. Preparation of graphene oxide-reinforced calcium phosphate/calcium sulfate/methylcellulose-based injectable bone substitutes. MRS Commun. 2019;9(4):1174-1180. doi: $10.1557 / \mathrm{mrc} .2019 .125$

135. Li J, Jiang H, Ouyang X, et al. CaCO3/tetraethylenepentaminegraphene hollow microspheres as biocompatible bone drug carriers for controlled release. ACS Appl Mater Interfaces. 2016;8 (44):30027-30036. doi:10.1021/acsami.6b10697

136. Tang J, Cao WJ, Zhang Y, et al. Properties of vaterite-containing tricalcium silicate composited graphene oxide for biomaterials. Biomed Mater. 2019;14(4):045004. doi:10.1088/1748-605x/ab0de3

137. Dai CB, Li Y, Pan WZ, et al. Three-dimensional high-porosity chitosan/honeycomb porous carbon/hydroxyapatite scaffold with enhanced osteoinductivity for bone regeneration. ACS Biomater Sci Eng. 2020;6 (1):575-586. doi:10.1021/acsbiomaterials.9b01381

138. Li JF, Liu X, Tomaskovic-Crook E, Crook JM, Wallace GG. Smart graphene-cellulose paper for 2D or 3D "origami-inspired" human stem cell support and differentiation. Colloid Surf B-Bio Interfaces. 2019;176:87-95. doi:10.1016/j.colsurfb.2018.12.040

139. Liu SK, Zhou CC, Mou S, et al. Biocompatible graphene oxide-collagen composite aerogel for enhanced stiffness and in situ bone regeneration. Mater Sci Eng C-Mater Biol Appl. 2019;105:110137. doi:10.1016/j.msec.2019.110137

140. Unagolla JM, Jayasuriya AC. Enhanced cell functions on graphene oxide incorporated 3D printed polycaprolactone scaffolds. Mater Sci Eng C-Mater Biol Appl. 2019;102:1-11. doi:10.1016/j. msec.2019.04.026

141. Bhusari SA, Sharma V, Bose S, Basu B. HDPE/UHMWPE hybrid nanocomposites with surface functionalized graphene oxide towards improved strength and cytocompatibility. $J R$ Soc Interface. 2019;16(150):20180273. doi:10.1098/rsif.2018.0273

142. Feng ZY, Li Y, Hao L, et al. Graphene-reinforced biodegradable resin composites for stereolithographic 3D printing of bone structure scaffolds. J Nanomater. 2019;2019:9710264. doi:10.1155/ 2019/9710264

143. Liu C, Wong HM, Yeung KW, Tjong SC. Novel electrospun polylactic acid nanocomposite fiber mats with hybrid graphene oxide and nanohydroxyapatite reinforcements having enhanced biocompatibility. Polymers. 2016;8(8):287. doi:10.3390/polym8080287

144. Qi C, Deng Y, Xu LM, et al. A sericin/graphene oxide composite scaffold as a biomimetic extracellular matrix for structural and functional repair of calvarial bone. Theranostics. 2020;10 (2):741-756. doi:10.7150/thno.39502

145. Zhang WJ, Chang Q, Xu L, et al. Graphene oxide-copper nanocomposite-coated porous $\mathrm{CaP}$ scaffold for vascularized bone regeneration via activation of Hif- $1 \alpha$. Adv Healthc Mater. 2016;5(11):1299-1309. doi:10.1002/adhm.201500824

146. Halim A, Liu L, Ariyanti AD, Ju Y, Luo Q, Song GB. Low-dose suspended graphene oxide nanosheets induce antioxidant response and osteogenic differentiation of bone marrow-derived mesenchymal stem cells via JNK-dependent FoxO1 activation. J Mat Chem B. 2019;7(39):5998-6009. doi:10.1039/c9tb01413f

147. Zhao M, Dai YK, Li XB, et al. Evaluation of long-term biocompatibility and osteogenic differentiation of graphene nanosheet doped calcium phosphate-chitosan AZ91D composites. Mater Sci Eng C-Mater Biol Appl. 2018;90:365-378. doi:10.1016/j. msec.2018.04.082

148. Yu Z, Xiao CW, Huang YZ, et al. Enhanced bioactivity and osteoinductivity of carboxymethyl chitosan/nanohydroxyapatite/ graphene oxide nanocomposites. RSC Adv. 2018;8 (32):17860-17877. doi:10.1039/C8RA00383A
149. Yang X, Zhao Q, Chen YJ, et al. Effects of graphene oxide and graphene oxide quantum dots on the osteogenic differentiation of stem cells from human exfoliated deciduous teeth. Artif Cell Nanomed Biotechnol. 2019;47(1):822-832. doi:10.1080/ 21691401.2019.1576706

150. Yan XX, Yang W, Shao ZW, Yang SH, Liu XZ. Graphene/singlewalled carbon nanotube hybrids promoting osteogenic differentiation of mesenchymal stem cells by activating $\mathrm{p} 38$ signaling pathway. Int J Nanomed. 2016;11:5473-5484. doi:10.2147/IJN.S115468

151. Kim HD, Kim J, Koh RH, et al. Enhanced osteogenic commitment of human mesenchymal stem cells on polyethylene glycol-based cryogel with graphene oxide substrate. ACS Biomater Sci Eng. 2017;3(10):2470-2479. doi:10.1021/ acsbiomaterials.7b00299

152. Noh M, Kim SH, Kim J, et al. Graphene oxide reinforced hydrogels for osteogenic differentiation of human adipose-derived stem cells. RSC Adv. 2017;7(34):20779-20788. doi:10.1039/ C7RA02410J

153. Valles G, Bensiamar F, Maestro-Paramio L, Garcia-Rey E, Vilaboa N, Saldana L. Influence of inflammatory conditions provided by macrophages on osteogenic ability of mesenchymal stem cells. Stem Cell Res Ther. 2020;11(1):57. doi:10.1186/ s13287-020-1578-1

154. Li C, Li GQ, Liu M, Zhou TT, Zhou HB. Paracrine effect of inflammatory cytokine-activated bone marrow mesenchymal stem cells and its role in osteoblast function. J Biosci Bioeng. 2016;121 (2):213-219. doi:10.1016/j.jbiosc.2015.05.017

155. Ma J, Liu R, Wang X, et al. Crucial role of lateral size for graphene oxide in activating macrophages and stimulating pro-inflammatory responses in cells and animals. ACS Nano. 2015;9(10):10498-10515. doi:10.1021/acsnano.5b04751

156. Zheng YS, Pescatore N, Gogotsi Y, et al. Rapid adsorption of proinflammatory cytokines by graphene nanoplatelets and their composites for extracorporeal detoxification. $J$ Nanomater. 2018;2018:6274072. doi:10.1155/2018/6274072

157. Xue DT, Chen EM, Zhong HM, et al. Immunomodulatory properties of graphene oxide for osteogenesis and angiogenesis. Int $J$ Nanomed. 2018;13:5799-5810. doi:10.2147/IJN.S170305

158. Mathkar A, Narayanan TN, Alemany LB, et al. Synthesis of fluorinated graphene oxide and its amphiphobic properties. Part Part Syst Char. 2013;30(3):266-272. doi:10.1002/ppsc.201200091

159. Enayati M, Nemati A, Zarrabi A, Shokrgozar MA. The role of oxygen defects in magnetic properties of gamma-irradiated reduced graphene oxide. J Alloys Compd. 2019;784:134-148. doi:10.1016/j.jallcom.2018.12.363

160. Yang YQ, Chen SZ, Li HD, et al. Engineered paramagnetic graphene quantum dots with enhanced relaxivity for tumor imaging. Nano Lett. 2019;19(1):441-448. doi:10.1021/acs. nanolett. $8 \mathrm{~b} 04252$

161. Gizzatov A, Keshishian V, Guven A, et al. Enhanced MRI relaxivity of aquated $\mathrm{Gd} 3+$ ions by carboxyphenylated water-dispersed graphene nanoribbons. Nanoscale. 2014;6(6):3059-3063. doi:10.1039/c3nr06026h

162. Pramanik N, De J, Basu RK, Rath T, Kundu PP. Fabrication of magnetite nanoparticle doped reduced graphene oxide grafted polyhydroxyalkanoate nanocomposites for tissue engineering application. RSC $A d v$. 2016;6(52):46116-46133. doi:10.1039/ C6RA03233H

163. Pang L, Dai CQ, Bi L, Guo ZS, Fan JJ. Biosafety and antibacterial ability of graphene and graphene oxide in vitro and in vivo. Nanoscale Res Lett. 2017;12:564. doi:10.1186/s11671-017-2317-0

164. Roșu MC, Pall E, Socaci C, et al. Cytotoxicity of methylcellulose-based films containing graphenes and curcumin on human lung fibroblasts. Process Biochem. 2017;52:243-249. doi:10.1016/j.procbio.2016.10.002 
165. Wychowaniec JK, Litowczenko J, Tadyszak K. Fabricating versatile cell supports from nano- and micro-sized graphene oxide flakes. J Mech Behav Biomed Mater. 2020;103:103594. doi:10.1016/j.jmbbm.2019.103594

166. Gurunathan S, Kang M, Jeyaraj M, Kim JH. Differential cytotoxicity of different sizes of graphene oxide nanoparticles in Leydig (TM3) and Sertoli (TM4) cells. Nanomaterials. 2019;9 (2):139. doi:10.3390/nano9020139

167. Akhavan O, Ghaderi E, Akhavan A. Size-dependent genotoxicity of graphene nanoplatelets in human stem cells. Biomaterials. 2012;33(32):8017-8025. doi:10.1016/j.biomat erials.2012.07.040

168. Wu YK, Wang FF, Wang SH, et al. Reduction of graphene oxide alters its cyto-compatibility towards primary and immortalized macrophages. Nanoscale. 2018;10(30):14637-14650. doi:10.10 39/c8nr02798f

169. Dervin S, Murphy J, Aviles R, Pillai SC, Garvey M. An in vitro cytotoxicity assessment of graphene nanosheets on alveolar cells. Appl Surf Sci. 2018;434:1274-1284. doi:10.1016/j.apsusc. 2017.11.217
170. Syama S, Mohanan PV. Safety and biocompatibility of graphene: a new generation nanomaterial for biomedical application. Int J Biol Macromol. 2016;86:546-555. doi:10.1016/j.ijbiomac. 2016.01.116

171. Zhou K, Yu P, Shi XJ, et al. Hierarchically porous hydroxyapatite hybrid scaffold incorporated with reduced graphene oxide for rapid bone ingrowth and repair. ACS Nano. 2019;13(8):9595-9606. doi:10.1021/acsnano.9b04723

172. Li YJ, Feng LZ, Shi XZ, et al. Surface coating-dependent cytotoxicity and degradation of graphene derivatives: towards the design of non-toxic, degradable nano-graphene. Small. 2014;10 (8):1544-1554. doi:10.1002/smll.201303234

173. Huang Y, Lu XY, Lu XQ. Cytotoxic mechanism for silver nanoparticles based high-content cellomics and transcriptome sequencing. $J$ Biomed Nanotechnol. 2019;15(7):1401-1414. doi:10.1166/jbn.2019.2785

174. Lee ES, Kim SH. Fabrication of size-controlled linoleic acid particles and evaluation of their in-vitro lipotoxicity. Food Chem Toxicol. 2017;100:50-61. doi:10.1016/j.fct.2016.12.005
International Journal of Nanomedicine

\section{Publish your work in this journal}

The International Journal of Nanomedicine is an international, peerreviewed journal focusing on the application of nanotechnology in diagnostics, therapeutics, and drug delivery systems throughout the biomedical field. This journal is indexed on PubMed Central, MedLine, CAS, SciSearch ${ }^{\mathbb{}}$, Current Contents ${ }^{\mathbb{R}} /$ Clinical Medicine,
Dovepress

Journal Citation Reports/Science Edition, EMBase, Scopus and the Elsevier Bibliographic databases. The manuscript management system is completely online and includes a very quick and fair peer-review system, which is all easy to use. Visit http://www.dovepress.com/ testimonials.php to read real quotes from published authors. 